\title{
The Veblen-Gerschenkron Effect of FDI in Mezzogiorno and East Germany*
}

\author{
Giovanni Peri†and Dieter Urban ${ }^{\ddagger}$
}

August 22, 2002

\begin{abstract}
The presence of foreign multinational enterprises (MNEs) can benefit local economies. In particular, if MNEs are very productive compared to domestic firms, they may promote learning and catch-up of local firms. Such a channel of spillovers from MNEs to local firms is known as the Veblen-Geschenkron effect. Rather than the overall density of MNEs in a region or sector, it is their initial productivity advantage on the local firm to determine the positive effect on domestic productivity growth. We test this hypothesis using firm level data for German and Italian companies during the 90ies and we find evidence of a significant and robust Veblen-Gerschenkron effect.

Key Words: Veblen-Gerschenkron Effect, FDI, Spillovers, Productivity.

JEL Classification Codes: F23, O47, R11.
\end{abstract}

${ }^{*}$ This paper was partly written while Urban was TMR-fellow at the Centro Studi Luca d'Agliano. Financial support from the European Commission Fifth Framework Programme (Grant No. FMRX-CT0215) is gratefully acknowledged. We owe particular thanks to Deutsche Bundesbank for providing us with unpublished regional data on foreign owned firms in Germany. We thank Giorgio Barba Navaretti and Steve Redding for their comments. Arturo de Visdomini provided excellent research assistance. The usual disclaimer applies.

†University of California Davis, One Shields Avenue, Davis CA, 95616, USA, gperi@ucdavis.edu.

†London School of Economics and Political Science, CEP, Houghton St, London WC2A 2AE, U.K., D.M.Urban@lse.ac.uk. 


\section{Introduction}

As the interest for the phenomenon of "globalization" grows among social scientists and media communicators the study of multinational enterprises (MNEs), probably the most recognizable symbol of globalization, attracts a lot of interest. Economists and policy makers strive to answer the question: do foreign direct investments (FDI) benefit or harm the local economy? Through what channles do positive and negative effects operate?

Theoretically can be argued either way. On one hand multinationals could be an important vehicle for technology transfer to a country (Findlay [16], Das [11], and Wang and Blomström [52]), they could benefit local suppliers and local consumers (Rodriguez-Clare [46] and Markusen and Venables [43]) and they could increase the human capital of the local labor force (Fosfuri, Motta, and Rønde [18], and Glass and Saggi [23], [22]). On the other hand, they could out-compete local firms forcing them out of production without employing local labor because of skill mis-match (Aitken and Harrison [1]). The theoretical literature provides structure and proposes determinants of spillovers but ultimately only the empirical analysis can answer the question. So far, the evidence has been ambiguous depending on the data and the methods used ${ }^{1}$. Our contribution focuses on a potentially important and little inquired channel through which foreign firms may affect local economies: the so called Veblen-Gerschenkron effect.

Since spillovers of foreign firms on local ones are not directly measurable ${ }^{2}$, we need to identify some characteristics that affect these spillovers from foreign firms and test their effect on local productivity. Previous studies have identified the following five determinants of spillovers from FDI: (1) the total amount of MNEs present in a country; (2) the technological proximity of those MNEs to local firms; (3) the spatial proximity of those

\footnotetext{
${ }^{1}$ For surveys see Blomström and Kokko [6] and Görg and Greenaway [24]. An interesting meta-study of the different research results is Görg and Strobl [25] which shows that the results depend on the research design.

${ }^{2}$ There are some attempts to come closer to a direct measurement. Branstetter [8] uses patent citation data, Cassiman and Veugelers [9] rely on survey data, and Soussa [48] measures training of workers in MNEs and indigenous firms. Each of these studies address specific channels of spillovers, but they do not analyse the overall impact of spillover effects.
} 
MNEs to local firms; (4) the size of the technological gap between local firms and MNEs (Veblen-Gerschenkron effect) and (5) the absorptive capacity of indigenous firms in adopting MNE technology. While these factors could be working together and reinforcing each other most of the empirical research has focused primarily on factors (1)-(3) measuring the effect of foreign owned firms in some sectors and countries on the productivity of domestic firms ${ }^{3}$. In the present paper, while controlling for the effect of MNE density in geographical and technological proximity, we concentrate on the Veblen-Gerschenkron effect and on the absorptive capacity hypothesis. Much less has been said about these two channels.

First formalized by Findlay [16] who dates it back to the contribution of Veblen [51] and Gerschenkron [20] the hypothesis states that regions or countries with a large initial technological gap are more likely to benefit from spillovers of FDI. As a consequence they may experience stronger growth of total factor productivity relative to advanced regions or countries. To our knowledge only Kokko [42], Sjöholm [47], Girma [27] and Griffith et al. [31] have attempted to take this effect into account. They mainly analyze the sector dimension of this type of spillovers. Kokko [42] calculates the average (rather than TFP) productivity gap of foreign and indigenous firms by industry and divides the sample into high and low gap observations. Contrary to the Veblen-Gerschenkron effect, spillovers are stronger in the low-gap sample half. Sjöholm [47] splits the firm observations in two equally sized groups: those with industries that have a large gap of total factor productivity and those that have a small gap and estimates separately their production functions. He finds that MNE density has a stronger impact on industries with large technology gaps if one excludes enclave industries. However, the sample split is chosen arbitrarily and no regional dimension is taken into account, nor is technology catch-up explicitly modeled.

Griffith et al. [30] derive the estimation from a theoretical model and calculate from factor cost shares total-factor-productivity gaps of firms to the industry technology frontier on UK manufacturing establishments. While there is catch up to the frontier, this catch up is not stronger if the frontier firm is foreign-owned. Girma [27] estimates the

\footnotetext{
${ }^{3}$ Surveys are Blomström and Kokko [6] and Greenaway and Goerg [24]. More recent papers are: Halpern and Körösi [32], Angelucci et al. [2], Dimelis and Louri [14], Djankov and Hoekman [15], Girma and Wakelin [29], Braconier et al. [7], Kinoshita [40], and Konings [41].
} 
productivity gap of a firm to the industry frontier and investigates the absorptive capacity of an indigenous firm to benefit from spillovers of the industry frontier firm by applying threshold regression techniques.

Contrarily to the previous literature, our focus is on the regional dimension of the Veblen-Gerschenkron spillover effect as several studies have pointed out the localized nature of knowledge spillovers (see Jaffe and Trajtenberg [36] Section II for a survey). We use two geographically detailed data sets that have not been used before to address this question. They contain data from a sample of domestic and foreign-owned manufacturing firms in Germany for the period 1993-1999 and in Italy for the period 1992-1998. We also use other regional data on 16 Laender in Germany and 103 Provinces in Italy.

Italy and Germany are two particularly interesting countries for such analysis. First, they include highly productive and advanced regions (Western Germany and Northern Italy) as well as relatively backward ones (Eastern Germany and the Mezzogiorno) allowing a large range of variability in firm productivity. Second, the less developed regions exhibit a substantial technology gap between multinational and local firms (although not so large as to be prohibitive). Finally the political, institutional and legal variables are common to all regions within a country and therefore are fully controlled for. While historically very different, the problem of underdevelopment of a part of the country relative to the other is of the greatest concern for the government of both Italy and Germany. Our contribution addresses also the potential role of FDI in facilitating the economic catch-up of the lagging regions reducing the existing economic disparities.

We test the Veblen-Gerschenkron hypothesis using a two-stage estimation procedure. In the first stage, we estimate the region (for Italy the sector-region) specific component of total factor productivity for national and multinational firms from about 45,000 Italian and 1,000 German firms. In the second stage, we use these estimates of regional productivity (or, for Italy, sector-region productivity) to perform a panel analysis for Germany and a cross section for Italy. Specifically, we measure FDI intensity in a region and the initial total factor productivity gap between national and foreign owned firms and we consider the effect of these variables on the subsequent growth rate of productivity of indigenous firms controlling for other potential determinants of growth. 
Our econometric results detect the presence of a relevant Veblen-Gerschenkron spillover effect as the initial productivity gap between local MNEs and local domestic firms seem positively and significantly correlated with the productivity growth of domestic firms. Such finding is robust to some alternative hypothesis and standard robustness checks. We discuss and check several potential explanations for this effect.

The rest of the paper is organized as follows. Section 2 describes our econometric model and the estimation strategy used pointing out the differences in implementing the method for German and Italian data. Section 3 describes the data, and the productivity estimates for national and multinational firms in regions and provinces of the two countries. Section 4 estimates the effect of multinational density and the Veblen-Gerschenkron effect on productivity-growth of local firms. Section 5 concludes.

\section{Empirical Model}

\subsection{Specification}

We propose a two stage estimation strategy to investigate the Veblen-Gerschenkron effect of FDI spillovers. The first stage of our model identifies the region-sector-time specific total factor productivity level (TFP) and productivity growth for national and multinational firms. We estimate the following firm-level Cobb Douglas production function, allowing for province-sector-time specific TFP both for indigenous firms and MNEs:

$$
\ln \left(Y_{i t}\right)=a_{0}+a_{1} \ln \left(L_{i t}\right)+a_{2} \ln \left(K_{i t}\right)+a_{3} \ln \left(M_{i t}\right)+\sum_{s \in S} d_{s} D_{s}+v_{p s t}+\varepsilon_{i t},
$$

where $Y_{i t}$ is the value of sales of firm $i$ at time $t, L_{i t}$ the number of employees, $K_{i t}$ the real fixed assets and $M_{i t}$ the real cost of materials. $D_{s}$ are sector dummies for the set of all sectors $S, a_{1}, a_{2}, a_{3}$ and $d_{s}$ are regression coefficients ${ }^{4}, \varepsilon_{i t}$ is an i.i.d. zero-mean error term. We specify region-industry-time fixed effects $v_{p s t}$ as follows:

\footnotetext{
${ }^{4}$ For Italian data, we allow the coefficients $a_{1}, a_{2}, a_{3}$ to be industry-specific.
} 


$$
v_{p s t}=\sum_{s \in S} \sum_{p \in P} \sum_{t \in T}\left[A_{p s t}^{N} \cdot D_{p s t}^{N}+A_{p s t}^{M} \cdot D_{p s t}^{M}\right]
$$

$A_{p s t}^{N}$ is the estimated $\ln (T F P)$ of the average domestic firms in region $p$, sector $s$, at time $t$. $A_{p s t}^{M}$ is the estimated TFP of the average MNEs in region $p$, sector $s$, at time $t .^{5} D_{p s t}^{N}$ and $D_{p s t}^{M}$ are the corresponding dummy variables.

Next, we define average productivity growth of indigenous firms in period $t, g_{p s t}^{N} \operatorname{as}^{6}$ :

$$
g_{p s t}^{N}=A_{p s, t}^{N}-A_{p s, t-1}^{N}
$$

and importantly the productivity gap of MNEs and indigenous firms in a sector $s$ and region $p$ at the end of period $t$ as:

$$
\operatorname{gap}_{p s t}=A_{p s t}^{M}-A_{p s t}^{N}
$$

The productivity gap captures the scope for technological catch-up between foreign firms and domestic ones. As Veblen [51] and Gerschenkron [20] argued, the size of the spillovers depends positively on the relative backwardness of a region: the larger the gap the greater is the potential for indigenous firms to learn from the MNEs.

In order to test this hypothesis in the second stage, we estimate a productivity growth equation using the estimated productivity measures by region, province and time as follows:

$$
g_{p s t}^{N}=b_{0}+b_{1} \cdot A_{p s, t-1}^{N}+b_{2} \cdot g a p_{p s, t-1}+b_{3} \cdot M N E d e n s i t y_{p s, t-1}+\sum_{p \in P} d_{p} D_{p}+\nu_{p s t},
$$

where $M N$ Edensity $_{p s, t-1}$ denotes the ratio of MNE employment to employment in indigenous firms in a region $p$, sector $s$, and time $t-1, D_{p}$ are region-dummies and $\nu_{p s t}$ is a zero mean i.i.d. error term. The basic structure of this estimation equation is very similar to the one proposed in Findlay [16]: a large productivity gap between MNEs and domestic firms,

\footnotetext{
${ }^{5} S, P$ and $T$ are the sets of sectors, regions and years in the data sample, respectively.

${ }^{6}$ As the production function is estimated in logarithms the growth rate is defined as log change of TFP.
} 
generates scope for learning of indigenous firms. The existence of a Veblen-Gerschenkron effect implies that the coefficient $b_{2}$ is positive. In addition, we control for the commonly studied measure of spillover effects - density of MNEs $(M N E \text { density })^{7}$ - and for the usual TFP-convergence term - initial productivity of indigenous firms $\left(A_{p s, t-1}^{N}\right)$.

Notice that the productivity gap estimated in equation (4) does not capture a generic sector-region effect. The variable is obtained as difference between MNE's and domestic firms' productivity in the same sector, region and period. Any location-specific unobservable characteristic affecting productivity growth of all companies would be differenced away.

The convergence coefficient $b_{1}$ captures the dynamics of productivity around its balanced growth path (BGP) assuming that we have included among the regressors the determinants of BGP productivity. Sectors hit by some specific random shocks tend to move back towards their BGP productivity level as long as the coefficient $b_{1}$ is negative.

While (1) and (5) denote our ideal specification, we have to adjust our empirical model to match our data sets of Italian and German data. For Italy, the number of sampled firms increased over time. To avoid the noise of year-to-year variation, that could be driven by varying sampling errors, we estimate the productivity growth over the entire period rather than for each year. Therefore, we adjust the fixed effects $v_{p s t}$ of specification (1) for Italian data as follows:

$$
v_{p s t}=\sum_{s \in S} \sum_{p \in P}\left[A_{p s}^{N} \cdot D_{p s}^{N}+A_{p s}^{M} \cdot D_{p s}^{M}+g_{p s}^{N} \cdot D_{p s}^{N} \cdot t+g_{p s}^{M} \cdot D_{p s}^{M} \cdot t\right],
$$

where $t$ is a time trend and therefore $g_{p s}^{M}$ and $g_{p s}^{N}$ are the estimated growth rates of productivity of MNE and domestic firms. These coefficients are directly used in the second stage regression. No such problem exists for German data as the sample of firms is stable across years. However, as there is not sufficient coverage of sectors across regions, we drop the sector index in the second stage regression and analyze the average productivity for a whole region (Land). We still keep sector dummies in the first stage estimation.

\footnotetext{
${ }^{7}$ See Aitken and Harrison [1] and the survey of Goerg and Greenaway [24] for such kind of studies.
} 


\subsection{Estimation Issues}

We discuss here some important issues encountered in estimating equation (5). First, the dynamic specification assumes that the initial MNE density and the initial productivity gap do not depend on subsequent productivity growth of national firms. This seems reasonable even if we assume that MNE location decisions are taken with rational expectations. Those firms should not be concerned with the future growth of local companies when deciding where to locate. ${ }^{8}$

Second, the variables $A_{p s t}^{N}$ and $g_{p s t}^{N}$ are estimated from the same first stage regression, and therefore potentially subject to the same measurement errors. In order to check for inconsistency of the estimates, we also perform an IV estimation of equation (5). In particular as an instrument for $A_{p s t}^{N}$, which was obtained from production function estimations, we use the values of $A_{p s t}^{N}$ obtained from wage regressions using average firm wage costs on the left hand side of (1) instead of sales, and similarly for the initial gap pst. As average wage and sales per worker are both measures of productivity we have an instrument for TFP which is uncorrelated with the measurement error of sales. This strategy should grant the consistency of the estimates, in particular of the parameter $b_{2}$.

Third, it is often argued that the extent of product market competition may be relevant for the size of spillover effects (see Kokko [42], Haskel et al. [34], Keller and Yeaple [39] for econometric analysis and Wang and Blomstroem [52] for a theoretical model). Unfortunately we do not have measures of competition in a market. However as long as the level of competition varies mostly at the industry level it should be taken care of by industry fixed effects. Moreover we control for the number of multinationals in the region, which could be considered itself a proxy for the level of competition.

We are aware that omitted variables, such as workers' skills or capacity utilization, not included in estimating the production function in equation (1) would result in an excessive estimated variance of TFP, as TFP is probably correlated with these unmeasured factors.

\footnotetext{
${ }^{8}$ For Italian data we have an endogeneity problem, because we have to use MNE density in the final year rather than the first, as we can approve representativeness of this variable only towards the end. (See the data-appendix.)
} 
This overestimate of the variance of the gap would generate a downward bias in the estimate of the coefficient $b_{2}$ which therefore could be considered as a lower bound of the intensity of the Veblen-Gerschenkron effect.

Moreover, some interpretation issues arise: does our coefficient $b_{2}$ genuinely capture spillovers? The productivity of domestic firms may increase in the presence of highly productive MNEs simply as an effect of competition. MNEs crowd out weak domestic competitors forcing them to leave the market and average productivity of surviving indigenous firms rises ${ }^{9}$. While this is per se an interesting channel we distinguish it from the Veblen-Gerschenkron effect by analyzing the correlation of the gap-term with the subsequent change in domestic employment. Only if the gap is negatively correlated with employment growth and negative employment growth affects positively productivity growth the channel described above can be at work. We will see that this does not seem to be the case.

Finally, we investigate whether the Veblen-Gerschenkron technology spillover effect requires a minimum human capital endowment of a region to provide a sufficient absorptive capacity to indigenous firms. For this purpose, we apply a threshold regression technique ${ }^{10}$.

\section{Productivity and foreign owned firms}

The results of the first-stage regressions are qualitatively similar for Italy and Germany and we present them together in this section after a brief description of the data for each country.

\subsection{Data and Summary Statistics: Italy}

The data on Italian firms contain about 45,000 units in the manufacturing sector in 1998 and about 160,000 single observations over the time period 1992 to 1998 . The database

\footnotetext{
${ }^{9}$ See analogue arguments in Aitken and Harrison (1999) and Barry et al. (2001).

${ }^{10}$ This idea has been formalized in Keller [37] and Glass and Saggi [21] and tested in several recent papers such as Braconier et al. [7], Konnings [41], Kinoshita [40], and Girma [27] using traditional measures of foreign presence in an industry.
} 
of Centro Studi Luca d'Agliano is a merger of the AIDA database of Bureau van Dijk with balance sheet and profit and loss account information and the MNE database of Politecnico Milano, which contains ownership information. We have an unbalanced panel in the firm-time dimension. The observations on firms' balance sheets include data on the number of employees on the wage cost, on the values of sales, on the value of materials used as intermediates, on fixed assets of the company, its sector, location and name. We use the complete universe of foreign owned firms, defined as those firms with a non-zero share of voting rights held by foreigners.

In 1998 total employment in foreign firms was 402,704 employees the bulk of which, about 150,000, was concentrated in the province of Milano. The detailed description of the procedure used to clean some outliers and unrealistic breaks in the data is described in the appendix. ${ }^{11}$ Table 1 reports the average values for the variables we use for the year 1998, divided into national and foreign owned companies and into North and South. ${ }^{12}$

\section{Insert Table 1 here}

MNEs are on average larger than national firms, and firms in the North are on average larger than those in the South. MNEs pay larger wages and have larger average labor productivity than domestic firms. Wages and production per worker are larger in the North than in the South. Southern firms seem to be more capital intensive probably because of the lower worker's productivity, in spite of lower wages.

Multinational firms are mostly concentrated in the North of Italy. We report in figure 1 the density of multinational firms (MNEdensity) calculated as employment in MNE divided by employment in domestic firms, relative to the average value for Italy measured in 1998. A value of one for $M N E$ density means that the province has the same employment in multinational relative to national firms as the Italian average.

\footnotetext{
${ }^{11} \mathrm{An}$ investigation of the representativeness of our firm data compared to official aggregate data is provided in the data-appendix.

${ }^{12}$ Southern regions are Abruzzo, Molise, Campania, Calabria, Basilicata, Puglia, Sicilia and Sardegna.
} 


\section{Insert Figure 1 here}

While the highest relative concentration of MNE is in the Center-North, there are large differences in MNE density among the Southern provinces. Interestingly the northern part of the Mezzogiorno (northern Campania and Abruzzo) shows a high concentration of foreign owned firms in 1998. Some isolated provinces in the South, also had an unusually large concentration of multinationals. Certainly, though, all the provinces with lower concentration of foreign owned firms, except for very few, were located in the South. In particular all the provinces without any foreign owned firm (Agrigento, Caltanissetta, Campobasso, Enna, Foggia, Lecce, Nuoro, Ragusa, Sassari) are in the south and four of them are in Sicily.

\subsection{Data and Summary Statistics: Germany}

The firm data for Germany are obtained from the database Amadeus 200,000 of Bureau van Dijk. ${ }^{13}$ We use only manufacturing firms. The dataset covers about $2 \%$ of German manufacturing firms and about $28 \%$ of German manufacturing employment. We have an unbalanced panel of a bit less than 1000 manufacturing firms per year over the time period 1993-1999. ${ }^{14}$ We use data on employment, wage cost, sales, fixed assets (machinery, real estate, equipment, etc. ${ }^{15}$ ), and material costs. Additionally, the dataset contains information on the location, sector and ownership of the firms. We use a fairly broad regional aggregation, i.e. the 16 Laender ${ }^{16}$ to have a sufficient regional coverage of all types of firms. Unfortunately, there are no foreign owned firms in Sachsen (Saxony) in the

\footnotetext{
${ }^{13}$ Funke and Rahn [19] used these data to estimate firm TFP, but did not distinguish MNEs from domestic firms.

${ }^{14}$ The year 1999 is strongly underrepresented. Otherwise, the number of firms is fairly stable over time. See the data-appendix.

${ }^{15}$ We tried to find a good measure of the physical capital stock. Tangible fixed assets would have come closer to total fixed assets, but we would have faced the cost of too many missing values.

${ }^{16}$ The Laender correspond to the NUTS1 classification of EUROSTAT.
} 
dataset. $^{17}$

Consistently with the definition used for Italy, we define as MNEs in Germany all firms with reported non zero foreign participation. Relevant for ownership is the reported ultimate owner. Only if no information is available on the ultimate owner, the direct ownership determines the nationality of a firm. In general, we define also Western-owned firms in East Germany as multinational firms, since we are interested in spillovers and those may come as much from MNEs in West-Germany as from MNEs from other countries ${ }^{18}$. Companies of Treuhandanstalt, the privatization agency of the German government, are considered local firms. We have only ownership information for the most recent year of a firm record. Hence, we may mis-classify those firms which became multinationals by merging foreign firms during the considered period. The problem is alleviated though, because Bureau van Dijk tends to classify merged firms as new firms in the dataset. However, there are exceptions and we are unable to control for them. We will also use unpublished aggregate MNE activity data by Lander and year of Deutsche Bundesbank. Those data define MNEs as firms with foreign voting rights of at least $20 \%$ during the sample period. ${ }^{19}$ Those data include all sectors.

The averages of the variables in table 2 reveal that there are differences both across firm types (foreign owned, local owned) and across regions (East, West) ${ }^{20}$. In general, MNEs in the West are most capital intensive, more material intensive and face higher wage costs per employee on average. National firms in the East are less capital intensive and have lower wage costs per employee. Multinationals in East Germany use the least material inputs. This may indicate a lack of specialized input producers in East Germany. The Eastern firms in the sample are on average smaller than Western firms, and MNEs in the East are larger than national firms in the East.

\footnotetext{
${ }^{17}$ In fact, unpublished Bundesbank data show that there are hardly any foreign owned firms in Sachsen (Saxony). The ratio of employment in foreign owned firms to domestic owned firms is 0.009 in 1993 and even less in 1998.

${ }^{18}$ Criscuolo and Martin [10] show that UK-owned MNEs in the UK have the same productivity advantage over UK firms with no plants abroad than have foreign-owned MNEs in the UK.

${ }^{19}$ More information on these data may be found in Deutsche Bundesbank [12].

${ }^{20}$ Berlin is counted as a "Western" Land despite its geographical location in the East.
} 


\section{Insert Table 2 here}

This dataset over-represents large firms since only firms that have more than 200 employees or more than 10 Mill. DM Assets or more than 10 Mill. DM Sales are included. Moreover, many observations are missing. Therefore, we investigate representativeness of the database thoroughly in the data-appendix by using aggregate data of Statistisches Bundesamt and Deutsche Bundesbank for comparison, and find that Eastern Germany as well as some industry sectors such as printing, textile, mill products manufacturing are under-represented, while car, primary metals, and stone, clay, glass and concrete products are overrepresented relative to the average ${ }^{21}$. The location information refers to the headquarter of corporations. The problem of misallocation of plants, though, is reduced by using unconsolidated accounts. Those come closer to a match of plant and firm location.

\section{Insert Figure 2 here}

The regional distribution of FDI in Germany for the year 1998 from Bundesbank data is shown in Figure 2. The reported index is the same as calculated for Italy - MNEdensity. We notice the highest concentration of MNEs around the German business centres Hamburg, Berlin and Frankfurt, and the smallest in Sachsen and Thueringen. While there is an overall decline of foreign ownership by $1 \%$ point per year during the period from 1993 until 1998, there is a marked difference in development across regions particularly in the East. While Brandenburg, Sachsen Anhalt, and Mecklenburg-Vorpommern increased the presence of MNEs at a moderate speed, Sachsen and Thueringen stayed at a very low level and even decreased the presence of MNEs. There was also reshuffling of ownership in the West. For example, Bremen increased significantly MNE employment density from a low initial level.

\footnotetext{
${ }^{21}$ We correct for the regional bias by using WLS estimation. The construction of weights using unpublished data from Bundesbank and published data from Statistisches Bundesamt is explained in the appendix.
} 


\subsection{First stage Estimation}

In order to establish that multinationals have the potential to generate spillovers which could affect positively the productivity of national firms, we show first that they are on average significantly more productive than national firms. Table 3 reports the estimates of the production function of firms, separately for Italy and Germany using a regression similar to the "first-stage" regression (1), but with the fixed effect term $v_{p s t}$ drastically simplified. We only estimate the production function adding a dummy for foreign owned firms (specification I and III) or three dummies for the combination of foreign and national firms in the rich and poor part of the country (specification II and IV). The estimated coefficients on these dummies provide a measure of the productivity advantage of foreign firms on national firms, and on how it varies in the rich or in the poor part of the country.

\section{Insert Table 3 here}

Some patterns emerge clearly in the two countries, in spite of several differences. The first is that the MNEs are on average significantly more productive than national firms, although the difference in productivity is much larger for Germany (12\%) than for Italy $(2 \%)$. Germany may attract more productive MNEs, or foreign-owned firms in Germany may be relatively skill intensive, whereas foreign-owned firms in Italy may be relatively low-skilled.

Interestingly, the productivity gap between foreign and domestically owned firms is rather homogeneous on the national territory of each country: in Italy MNEs are about $2 \%$ more productive than national firms both in the North and in the South; in Germany MNE are 12\% more productive than nationals both in the West and in the East. MNEs have lower productivity in the South of Italy and East of Germany than in the North and West respectively. Since foreign owned affiliates can be assumed to have access to the technology of the parent company, lower productivity cannot be due only to poorer technology of indigenous firms. If so, regional spillover effects from MNEs will not solve the underdevelopment problem entirely. Still, they may alleviate it. 
Finally, foreign firms in the "poor" part of the country are about as productive as domestic firms in the "rich" part of the country. This can be seen from specification II and IV in which we omitted the dummy "Indigenous firms in Rich Region" and the coefficient on the dummy "MNE in the Poor Region" is basically zero. Notice that MNEs in the rich region are significantly more productive than that (respectively $+2 \%$ in Italy and $+12 \%$ in Germany) while domestic firms in the poor part of the country are significantly less productive than that ( $-2 \%$ in Italy and $-13 \%$ in Germany).

We run a similar regression (results not reported) using the log of per capita wage as dependent variable. ${ }^{22}$ We obtain qualitatively similar results, in that wages paid by domestic firms in the rich part of the country, once we control for inputs and capital, are similar to wages paid by foreign firms in the poor part of the country. Also for wage data it is true that the differences between Northern and Southern Italy are smaller than differences between East and West Germany and so is the foreign-national productivity gap.

Finally, we replicate previous studies by using MNE employment shares by industry, province and year in the case of Italy and province and year from Germany ${ }^{23}$ to measure their effect on productivity of indigenous firms estimating a specification as (1). The results are shown in Table 4. Both for Italy and for Germany, a significant positive sign on the coefficient of the MNE employment share vanishes, as soon as firm fixed effects are included in the specification. Alternatively, running the same regression with all variables in time differences as in Haskel et al. [34] also renders the MNE employment share coefficient insignificant (not reported). Therefore, we do not find spillover effects for Italy using MNE employment share as proxy of the source of these spillovers.

\footnotetext{
${ }^{22}$ It is straight forward to derive that fixed effects of wage regressions represent TFP under some assumptions. Alternatively, one may want to refer to Fosfuri et al. [18] for another theoretical justification using different assumptions.

${ }^{23}$ In the case of Italy, the MNE employment share is constructed from the firm database; in the case of Germany, it is calculated from unpublished data of Deutsche Bundesbank and of data of Statistisches Bundesamt. Moreover, we did not apply WLS estimation on German data to keep our results as close as possible to the previous literature.
} 
Insert Table 4 here

\subsection{Initial productivity gap and productivity growth}

\subsubsection{Italy}

The main result from the first stage estimation is that we obtain a measure of the initial productivity gap between national and multinational firms in each province-sector, gap $_{p s}=$ $A_{p s}^{M}-A_{p s}^{N}$, and a measure of the growth of productivity of national firms for the provincesectors $g_{p s}^{N}$. As these are two key variables it is useful to show their estimated values and represent them on a map of Italian provinces. While in our empirical strategy we use the province-sector as unit of spillover diffusion, in our map we simply represent the two variables averaged by province across sectors. In figure 3 and 4 we report the values of gap $_{p s}$ and of growth rate $g_{p s}^{N}$ respectively. The gap between estimated TFP of National and Multinational firms shows which provinces have more to gain from the presence of multinationals, simply through catch-up of local firms on foreign firms.

\section{Insert Figure 3 here}

While in provinces without any MNE we cannot calculate this value and we have a missing observation (dotted regions) it is apparent that the "upper" part of the mezzogiorno (excluding the southernmost regions and the islands) has potential for intense catch-up. On average the center-south seems to be the area that can potentially gain most from the Veblen-Gerschenkron effect. While, clearly, several other factors affect the productivity growth of national firms, the estimated $g_{p s}^{N}$ by province, reported in Figure 4 confirm that the central-southern regions have done better compared to the South and the North.

Insert Figure 4 here 
While only a rigorous analysis could prove the existence of correlation between initial gap and productivity growth, the presented stylized evidence is suggestive and pushes us to inquire into this effect with greater care.

\subsubsection{Germany}

The estimates of the variables $\operatorname{gap}_{p t}$ and $g_{p t}^{N}$ for Germany are performed for each year (1993-98). We report in Figure 5 and 6 the value of the gap-variable at the beginning of the considered period (1993) and for the growth variable its average over the whole period 1993-1998, respectively. No clear East-West pattern emerges for the gap-variable. Thueringen, Rheinland-Pfalz and Berlin have the largest gap that could potentially foster their productivity growth. Unfortunately, we don't have any observation for Sachsen and Mecklenburg-Vorpommern.

\section{Insert Figure 5 here}

In contrast, the pattern of productivity growth for the 1993-98 period has a much clearer East-West divide. As figure 6 shows, the period considered is characterized by a generalized productivity-catch-up of the Eastern regions to the Western regions. This could be due to the initially lower productivity of Eastern regions, to their technological catch-up or to out-migration from the East that freed fixed local factors. ${ }^{24}$

\section{Insert Figure 6 here}

Interestingly, though, Mecklenburg-Vorpommern, the Land, in which local firms were among those with the lowest productivity and very little presence of MNEs, is the region that grew least in the East, while Rheinland-Pfalz, the region with larger productivity gap between national and foreign firms is the Land that grew most in the West. While

\footnotetext{
${ }^{24}$ For a regional growth analysis of Germany after the unification see Keller [38]. He obtains similar catch-up in TFP of Eastern Laender from aggregate data over the period from 1991 until 1996 . Our results suggest, however, that this catch-up did not continue from approximately 1998.
} 
suggestive, these are merely stylized facts. We now move to the formal econometric analysis performing the second stage regressions.

\section{Testing the Veblen-Gerschenkron Effect}

Using the first stage estimates of initial productivity and productivity gap we test the hypothesis that the productivity gap between national companies and MNEs in the same region (and sector) may stimulate the productivity growth of local firms. We also control for the simple density of multinationals in geographical and technological proximity of national companies. We estimate equation (5) for Italy and Germany focussing on the size and significance of coefficients $b_{2}$ and $b_{3}$. The first is the elasticity of national companies' productivity growth to the initial domestic-MNE productivity gap, the second is the elasticity of national companies' productivity growth to the MNE density in the region (and sector in the Italian case). Again we present the results for Italy first and for Germany last, commenting on their similarities and differences.

\subsection{Italy's Cross Section}

Table 5 summarizes the main results in the Italian case. We regress the average yearly productivity growth for each province-sector, estimated from the previous section on the gap variable measured in 1998, Gap. ${ }^{25}$ Using OLS estimates the gap variable is significant and positive when introduced by itself (specification I), and also when we control for the MNE density in the province and sector (specification II). The coefficients are elasticities and imply that increasing the gap between national and multinational productivity by $100 \%$ would result in increased yearly growth rates of domestic productivity of about $1.5 \%$. Interestingly, the MNE density variable is not significant and has even the wrong sign. Specifications III and IV are the same as I and II but they use instrumental variable estimation. While standard errors increase and significance of coefficients decreases, the

\footnotetext{
${ }^{25}$ Ideally, we would like to have the initial productivity gap in 1993 . Since selection bias is likely to be very large the first years of our sample and smaller towards the end, we choose to use the gap in 1998 as proxy variable assuming it to be highly correlated with the true initial gap.
} 
gap variable remains significant at the $10 \%$ level. Moreover, the size of the gap-coefficient does not change. These results suggest that the Veblen-Gerschenkron effect is the most relevant and robust channel through which MNEs presence affects the growth of local firms.

\section{Insert Table 5 here}

It is important to notice that the omission of some important variables, affecting both the quality of incoming MNEs and the growth rates of indigenous firms, may bias the OLS estimates. For instance some provinces are more attractive to highly productive MNEs because the local crime rate is low, the local government is more efficient and the local population is highly educated. The same characteristics could be responsible for sustained productivity growth and omitting them would bias up the coefficient on the Gap variable. As we can measure some of these socio-economic variables that potentially affect growth we run the regression including these controls and we report the results in Table 6. Following recent work (see Forni and Paba [17], Peri and Cunat [44]) we consider as potentially relevant for the regional growth of Italian provinces the degree of education of its labor force (measured as the share of illiterate people in the population in year 1991, illiterate 1991), the presence of organized crime measured by the density of homicides per thousand persons in 1985, murder 1985, and the participation to the local political community, measured by the turnout at a local referendum vote in 1974, referendum 1974. The last variable is considered in several studies (such as Putnam et al. [45]) as a good proxy for the "social capital" in Italian regions. While certainly other variables may have an important role in determining growth we believe that the inclusion of these provides a check of the robustness of the coefficient of the gap variable. Specification I in Table 6 shows the results obtained by including the controls.

\section{Insert Table 6 here}

Comparing the coefficient in specification I with those in specification I of Table 5, we notice that the size and significance of the gap variable has slightly decreased, while 
the effect of MNE density is still not significant. Our controls do not seem to have much predictive power. Only the social capital variable is weakly significant with a negative coefficient. As these are province-wide control variables and we know that different industries may have quite different growth rates within a province, their low significance is not a surprise. In order to fully account for unobserved regional characteristics, we include regional fixed effects in specification II. The gap variable remains significant and its coefficient is 0.014 . These checks do not support the idea of downward bias on the gap coefficient due to omitted variables. Overall, the evidence suggests that the simple presence of MNEs does not foster productivity growth of local firms, unless there is a productivity gap for the local firm to catch up to.

In specification III and IV, we investigate whether a large productivity gap drives weak indigenous firms out of business and rises through this channel, rather than by promoting catch-up, the average productivity of the surviving firms. Specification III includes the growth rate of the number of plants in a province from 1991 to 1996, and instruments it with the productivity gap variable. ${ }^{26}$ Neither the growth in number of plants (specification III) nor the growth in employment (specification IV) have any significant correlation with local productivity growth. Moreover, in the (unreported) first stage regression the initial productivity gap variable is not a significant predictor of employment growth and has the wrong sign, i.e. there is a positive relation between plant growth and productivity gap.

Finally, we do not have the universe of all Italian firms in our dataset (see data appendix). In fact, we have no productivity data either of indigenous or foreign-owned firms in about three quarters of all possible combinations of industry and province. ${ }^{27}$ One may argue that there are no domestic firms active in an industry, when the potential productivity gap is too large. Likewise, there may not be MNEs active if the productivity gap to indigenous firms is too small, since MNEs have to compensate local adjustment cost

\footnotetext{
${ }^{26}$ We employ data from the Italian censuses of production in 1991 and 1996 . We have unit of plants data by province and 2-digit industry. Unfortunately, the industry classification is not directly compatible with the one of our firm database. Hence, we aggregate data for manufacturing as a whole.

${ }^{27}$ Typically, there lack many industries in most provinces. In particular, MNEs do not cover all industries.
} 
disadvantages with a technology advantage. Hence, there may be a selection bias problem. In order to investigate selection bias, we run an (unreported) Heckman regression with employment, number of plant growth, number of plants in 1991, and number of employees in 1991 in the selection equations ${ }^{28}$. These first stage variables seem appropriate to capture the probability of missing indigenous or foreign owned firms in an industry and province. The selection equation is weakly significant and the productivity gap variable remains significant at the 1 per cent level.

\subsection{Germany's panel}

The German case provides a second test for the Veblen-Gerschenkron effect. On one hand, as we are considering larger geographical units and we are merging sectors together, this test might capture cross-sector and less localized spillovers. On the other hand, as we are using the year to year variation of productivity gap and productivity growth this test is more demanding, in that it requires the catch-up effect to work in the short-run. In this sense, the two studies reinforce each other. The second stage estimates for Germany are based on specification (5) and require the estimate of a panel.

\section{Insert table 7 here}

Specification I and II of Table 7 are estimated using OLS with robust standard errors. They confirm the finding that there is conditional convergence in the productivity levels of domestic firms and that the gap variable has a positive and significant effect on the domestic-firm productivity growth during the following year. Again, the simple measure of MNE density in the region ${ }^{29}$ does not have any significant effect. Specification III and IV apply instrumental variable techniques, where instruments are obtained in the same

\footnotetext{
${ }^{28}$ These are the only variables for which we have sufficiently detailed information on 103 provinces and 23 sectors obtained from the Italian censuses of production in 1991 and 1996. Unfortunately, we have some mismatch of industry classifications (see data-appendix).

${ }^{29}$ This variable is constructed from unpublished data of Deutsche Bundesbank on employment in foreignowned firms in all sectors and employment in all firms from Statistisches Bundesamt.
} 
way as for the Italian case, by using a wage regression. The productivity gap variable remains significant at the 5 per cent level. However, the coefficient becomes larger.

We also perform some robustness checks for the German case. Also in this case some initial controls at the regional level are used to capture local factors that may affect productivity growth. Given some limitation on the availability of regional data, we control for the $\log$ share of university graduates in the population lagged one year ${ }^{30}$ and for the investment in physical capital per inhabitant. ${ }^{31}$

\section{Insert table 8 here}

Table 8, specification I, presents the baseline panel regression including the control variables. The coefficient of the productivity gap variable remains positive and significant. The MNE density maintains its low and insignificant coefficient, while the initial level of human capital has a positive and weakly significant effect on productivity growth. This is consistent with the idea that human capital fosters productivity growth, possibly by providing skilled labor to innovative companies.

In specification II, we investigate the alternative hypothesis that average productivity growth rises, because competition from MNEs with large productivity advantages force domestic firms to cut their labor force, which increases their average productivity. While, indeed, there is a negative relation between domestic-firm productivity growth and employment growth in manufacturing in a Land, when instrumented by the productivity gap $^{32}$, this effect is not significant.

In specification III we replace the MNE density measure based on employment with the $\log$ of FDI stock in a Land as share of the physical capital stock. ${ }^{33}$ Not surprisingly,

\footnotetext{
${ }^{30}$ This variable stems from Statistisches Bundesamt.

${ }^{31}$ The capital stock of a Land in the year 1991 is obtained from Keller [38] and updated using investment data from Statistisches Bundesamt.

${ }^{32}$ In the first stage regression we obtain a negative coefficient of the productivity gap variable on employment growth, significant at the 10 per cent level.

${ }^{33}$ Contrary to FDI employment data, the unpublished FDI stock data of Deutsche Bundesbank are collected by law enforcement. The correlation between FDI stock data and FDI employment data by Land and year (128 observations) is 0.96 .
} 
also this alternative measure of MNE presence is not significant, while the productivity gap variable remains significant.

Finally, we note that in the context of dynamic panel estimators with small time dimension, there is an estimation bias that can be corrected by an Arellano and Bond [3] dynamic panel estimator. Although we have too few observations to confidently apply this technique, we still find that the productivity gap variable remains significant at the $1 \%$ level. ${ }^{34}$

\subsection{Spillovers' Absorptive Capacity}

Finally, we investigate the so called "absorptive capacity" hypothesis. ${ }^{35}$ In investigating this question we follow Braconier et al. [7], Konings [41], Kinoshita [40], and Girma [27]. We adopt the estimation technique of Girma [27] using threshold regressions (Hansen [33]).

In particular, we assume that technological growth of indigenous firms depends on the total factor productivity gap between MNEs and indigenous firms only if a region has a sufficient amount of human capital endowment. This captures the idea that catching up requires some skills and is not simply an effect of being less developed. We deviate in this choice of the threshold variable from Girma [27] who separates the sample according to the size of the technology gap of a firm to its most successful competitor within the same 5 -digit industry (which is often an MNE) ${ }^{36}$. We assume, in fact, that absorptive capacity is a regional characteristic rather than a firm characteristic.

We first search for an optimal threshold value of the regional human capital endowment in order to split the sample between regions with low and region with high human capital. Then we test for the significance of the sample split using a heteroscedasticity consistent Supremum-Wald-test.

\footnotetext{
${ }^{34}$ There is first-order, but not second-order autocorrelation. The Sargan-test for overidentifying restrictions is not significant. The last test has to be treated with caution in the presence of heteroscedasticity (see Arellano and Bond [3]).

${ }^{35}$ In econometric terms, we investigate a structural break in our results.

${ }^{36}$ However, we follow in spirit the model of Keller [37], who showed that a lack of human capital (accumulation) may constrain international technology spillover effects.
} 
An optimal threshold is found by following three steps as in Hansen [33]. First, a threshold variable is chosen and the data-set is sorted according to it. Then, the data-set is split into two parts for which the threshold variable is larger/smaller than a threshold value and the sample halves are estimated separately. This is repeated for each possible value of the threshold variable and the optimal threshold value is found by maximizing the joint $\mathrm{R}^{2}$ or a modified Wald test-statistic in the case of heteroscedasticity across both sample halves over all possible threshold values of the threshold variable. Finally, a bootstrap procedure is applied to find the probability distribution of the test statistic $^{37}$. The threshold regression technique is a generalization of a standard Chow-test for the case, when the split of the sample is not known a priori and has to be estimated endogenously.

We apply threshold regressions to the two baseline specifications for Germany and Italy from table 4 and 6 , respectively. As threshold variable we choose $H U M C A P$, a measure of human capital in the region (namely the share of population with university degree lagged one year for Germany and in the year 1991 for Italy).

When applying threshold regressions, we use a Supremum-Wald test which is heteroscedasticity consistent. Diebold and Chen [13] have shown that the bootstrap is also reliable in smaller samples and in the presence of autocorrelation. In a slight variation to Hansen [33], we allow only the regression constant and the productivity gap coefficient to vary across regions with high or low human capital endowment. This way, we ensure that the sample split is significant due to the differential impact of MNE productivity gaps on regions with large or low absorptive capacity rather than due to some other factors.

The results are shown in Table 9. Neither in the case of Italy nor in the case of Germany is a sample split significant. Hence, we do not find evidence that the absorptive capacity of a region depends crucially on its human capital level. Moreover, we find rather opposite effects for Germany and Italy. In the case of Germany, the regions with a low human capital endowment $^{38}$ show a slightly larger potential for spillover effects contrary to the absorptive capacity hypothesis. In contrast, the potential for MNE externalities on domestic firms is smaller in Italian provinces with low human capital endowment in line with the hypothesis

\footnotetext{
${ }^{37}$ The estimation and software is described in more detail in Straubhaar, Suhrcke and Urban [49].

${ }^{38}$ These are observations of some but not only East German Lander.
} 
of absorptive capacity. We can conclude that probably all regions in both countries have the minimum human capital endowment to benefit from technological imitation of MNE's. Nevertheless, the estimates of Italian data are fairly close to a significant threshold and the absorptive capacity of Southern regions (coefficient on the gap variable) is rather low at 0.01 .

\author{
Insert table 9 here
}

\title{
5 Conclusions
}

We have explored in this paper the relationship between foreign owned manufacturing companies ( FDI), and locally owned manufacturing companies focussing on the existence and determinants of spillovers from the first to the second in Germany and Italy. We used a new firm level dataset of manufacturing firms in Germany from 1993 to 1999 and in Italy from 1992 to 1998 and standard sources of regional aggregate data.

We find that the larger the gap of total factor productivity of multinational firms relative to comparable local firms the faster is the productivity catch-up of Italian and German local firms. This is what we call the Veblen Geschenkron effect. We find that this effect is the main channel through which local companies benefit from the presence of foreign companies. It is not their density to help the local economy but their technological advantage. Possibly, this is an effect of the "local public good" nature of technological knowledge: a few MNEs in the neighborhood may already be sufficient a source of demonstration to many indigenous firms as long as they have a large technological advantage on them. 


\section{References}

[1] Aitken B. and A. Harrison, 1999, Do domestic firms benefit from foreign direct investment? Evidence from Venezuela, American Economic Review, 89 (3), 605-18.

[2] Angelucci, M., S. Estrin, J. Konings, and Z. Zólkiewski, 2001, The effect of ownership and competitive pressure on firm performance in transition countries: Micro evidence from Bulgaria, Romania and Poland, CEPR Discussion Paper, No. 2985 (London).

[3] Arellano, M. and S. Bond, 1991, Some tests of specification for panel data: Monte Carlo evidence and an application to employment equations, Review of Economic Studies 58, 277-297.

[4] Barry, F., H. Görg and E. Strobl, 2002, Foreign direct investment and wages in domestic firms: Productivity spillovers vs labour-market crowding out, forthcoming in European Economic Review.

[5] Blomström, M., S. Globerman, and A. Kokko, 2000, The determinants of host country spillovers from foreign direct investment, CEPR Discussion Paper, No. 2350 (London).

[6] Blomström, M. and A. Kokko,1998, Multinational corporations and spillovers, Journal of Economic Surveys 12 (3), 247-277.

[7] Braconier, H., K. Ekholm and K. H. Midelfart Knarvik, 2000, Does FDI work as a channel for R\&D spillovers? Evidence based on Swedish data, forthcoming in Weltwirtschaftliches Archiv.

[8] Branstetter, L., 2000, Is foreign direct investment a channel of knowledge spillovers? Evidence from Japan's FDI in the United States, NBER Working Paper, No. 8015 (Cambridge, Ma).

[9] Cassiman, B., and R. Veugelers, 2002, Foreign subsidiaries as channel of international technology diffusion: Some direct firm level evidence from Belgium, forthcoming in American Economic Review. 
[10] Criscuolo, C., and R. Martin, 2002, Multinationals, foreign ownership and productivity in UK businesses, London School of Economics, mimeo.

[11] Das, S.,1987, Externalities, and technology transfer through multinational corporations, Journal of International Economics 22, 171-182.

[12] Deutsche Bundesbank, 2001, Kapitalverflechtung mit dem Ausland, Statistische Sonderveroeffentlichung 10 .

[13] Diebold, F.X., and C.Chen, 1996, Testing structural stability with endogenous breakpoint - A size comparison of analytic and bootstrap procedures, Journal of Econometrics 70, 221-241.

[14] Dimelis, S. and H. Louri, 2001, Foreign direct investment and efficiency benefits: A conditional quantile analysis, CEPR Discussion Paper No. 2868 (London).

[15] Djankov, S. and B. Hoekman, 2000, Foreign investment and productivity growth in Czech enterprises, World Bank Economic Review 14 (1), 49-64.

[16] Findlay R., 1978, Relative backwardness, direct foreign investment, and the transfer of technology: A simple dynamic model, Quarterly Journal of Economics 92 (1), 1-16.

[17] Forni, M. and S.Paba, 2000, The Sources of Local Growth: Evidence from Italy, Giornale degli Economisti e Annali di Economia 59(1), 1-49.

[18] Fosfuri, A., M. Motta and T. Rønde, 2001, Foreign direct investment and spillovers through workers' mobility, Journal of International Economics 53, 205-222.

[19] Funke, M. and J. Rahn, 2000, How efficient is the East German Economy? An exploration with micro data, University of Hamburg, mimeo.

[20] Gerschenkron A., 1952, Economic backwardness in historical perspective, in B.F. Hoselitz (ed.) The progress of underdeveloped areas, (University of Chicago Press, Chicago IL). 
[21] Glass, A.J., and K. Saggi, 1998, International Technology Transfer and the Technology Gap, Journal of Development Economics 55, 369-398.

[22] Glass, A.J., and K. Saggi, 1999, Foreign direct investment and the nature of R\&D, Canadian Journal of Economics 32 (1), 92-117.

[23] Glass, A.J., and K. Saggi, 1999, Multinational Firms and Technology Transfer, University of Texas, mimeo.

[24] Görg, H. and D. Greenaway, 2001, Foreign direct investment and intra-industry spillovers: A review of the literature, the University of Nottingham Research Paper Series, No. 2001/37.

[25] Görg, H. and E. Strobl, 2002, Multinational companies and productivity spillovers: A meta-analysis with a test for publication bias, forthcoming in the Economic Journal.

[26] Görg, H. and E. Strobl, 2000, Multinational companies and indigenous development: An empirical analysis, GLM Research Paper 2000/22, (University of Nottingham).

[27] Girma, S., 2002, Absorptive capacity and productivity spillovers from FDI: a Threshold Regression Analysis, University of Nottingham, mimeo.

[28] Girma, S., and K. Wakelin, 2000, Are there regional spillovers from FDI in the UK?, GLM Research Paper 2000/16 (University of Nottingham).

[29] Girma, S., and K. Wakelin, 2001, Regional underdevelopment: Is FDI the solution? A semiparametric analysis, CEPR Discussion Paper, No. 2995 (London).

[30] Griffith, R., J.V.Reenen, and S.Redding, 2000, Mapping the two faces of R\&D: Productivity growth in a panel of OECD industries, CEPR Discussion Paper No. 2457, (London).

[31] Griffith, R., S.Redding, and H.Simpson, 2002, Foreign ownership and technological convergence at the micro level, Institute for Fiscal Studies, mimeo. 
[32] Halpern, László, and Gábor Körösi, 2001, Efficiency and market share in the Hungarian corporate sector, Economics of Transition 9(3), 559-592.

[33] Hansen, B.E., 2000, Sample splitting and threshold estimation, Econometrica 68, 575-603.

[34] Haskel, J.E., S.C.Pereira, and M.J.Slaughter, 2002, Does inward foreign direct investment boost the productivity of domestic firms?, NBER Working Paper No. 8724 (Cambridge, Ma).

[35] Helpman, E., M. Melitz, and S. Yeaple, Exports versus FDI, Harvard University, mimeo.

[36] Jaffe, A. and M. Trajtenberg, 2002, Patents, Citations and Innovations, (The MIT Press, Cambridge, MA)

[37] Keller, W., 1996, Absorptive capacity: On the creation and acquisition of technology in development, Journal of Development Economics 49, 199-227.

[38] Keller, W., 2000, From socialist showcase to Mezzogiorno? Lessons on the role of technical change from East Germany's post-World war II growth performance, Journal of Development Economics 63, 485-514.

[39] Keller, W., and S.R. Yeaple, 2002, Multinational enterprises, international trade, and productivity growth: Firm-level evidence from the United States, ERWIT conference at Maximilians University Munich, mimeo.

[40] Kinoshita, Y., 2001, R\&D and technology spillovers through FDI: Innovation and Absorptive Capacity, CEPR Discussion Paper, No. 2775 (London).

[41] Konings, Jozef, 2000, The effect of direct foreign investment on domestic firms: Evidence from firm level panel data in emerging economies, CEPR Discussion Paper, No. 2586 (London).

[42] Kokko A., 1994, Technology, market characteristics, and spillovers, Journal of Development Economics 43, 279-293. 
[43] Markusen J. and A. Venables, 1999, Foreign Direct Investment as a Catalyst to industrial development, European Economic Review 43, 335-356.

[44] G.Peri and A.Cunat, 2001, Job Creation in Italy: Geography, Determinants and Perspectives, Giornale degli Economisti e Annali di Economia 61(1), 23-54.

[45] Putnam, R.D., R. Leonardi and R.Y. Nanetti, 1994, Making Democracy Work. Civic Traditions in Modern Italy, (Princeton University Press).

[46] Rodriguez-Clare A., 1993, Multinational, Linkages and Economic Development, American Economic Review 86 (4), 852-873.

[47] Sjöholm F., 1999, Technology gap, competition and spillovers from direct foreign investment: Evidence from establishment data, The Journal of Development Studies $36(1), 53-73$.

[48] Sousa, N., 2001, Multinationals and technology transfer through labour training, University of Nottingham, mimeo.

[49] Straubhaar, T., M.Suhrcke, and D.M.Urban, 2002, Divergence - Is it geography?, HWWA, mimeo

[50] Statistisches Bundesamt, 2000, Statistik regional, CD-ROM various issues.

[51] Veblen T., 1915, Imperial Germany and the industrial revolution, (London, Macmillan).

[52] Wang, J.-Y. and M. Blomström, 1992, Foreign investment and technology transfer, European Economic Review 36, 137-155. 


\section{A Data Description: Germany}

Firm level data are taken from the database Amadeus 200,000 of Bureau van Dijk. This database is updated in real time on-line. We took data in March 2001. Bureau van Dijk eliminates all observations which are older than 5 years. We completed the dataset by using an old CD-ROM from 1999. ${ }^{39}$ The firm matching between the two datafiles is incomplete, because the firm identification code changed slightly in some cases. We have made a case by case evaluation if in doubt. We have also run consistency checks on location information and adjusted 43 observations. We have eliminated all missing observations on the key variables. All firms without ownership information in the dataset are considered local owners. This is common practise for the database.

The few available observations for the year 2000 were excluded. Moreover, we have excluded observations according to several criteria: 1) All observations with growth rates of wage cost per employee of more than 100 percent or less than minus $50 \%$; 2) all observations for which capital stocks or sales data were reported as $0 ; 3$ ) all observations with average wage costs per employee of less than 30,000 DM and more than 1,000,000 DM. Some average wage cost data may be flawed since there may be a mismatch of the date of reporting of employees and the period over which wage costs are summed up. Also, restructuring of firms during the reporting period may be a cause for outliers. Finally, part-time work is not appropriately counted. Our regression results are not sensitive to changes in the exclusion criteria, only summary statistic are somewhat sensitive to these inclusion. Reported industry codes are US-SIC codes. We include only manufacturing firms with US-SIC codes 20-39. All observations without US-SIC code are eliminated.

Since there is an exclusion criteria for firms in Amadeus 200,000 (see main text), we investigate representativeness in the following. The number of firms across years is given in table A1.

\footnotetext{
${ }^{39}$ We thank Bocconi library for providing us with these data and Bureau van Dijk, office Milan, for giving us special permission for the use of these data.
} 
Table A1 : Number of German Firms by Year

$$
\begin{array}{cccccccc}
\text { Year } & 1993 & 1994 & 1995 & 1996 & 1997 & 1998 & 1999 \\
\text { Number of firms } & 912 & 979 & 1038 & 934 & 966 & 897 & 409
\end{array}
$$

Hence, there is no important break in the number of observations over time except for the year 1999 .

Table A2: Representativeness by Industry

$$
\begin{aligned}
& \text { Industry } \\
& \text { USSIC Employment by } \\
& \begin{array}{l}
\text { industry in 1998; } \\
\text { Statistisches }
\end{array} \\
& \text { Bundesamt }
\end{aligned}
$$

(1)

\begin{tabular}{|l|}
\hline Ernährungsgewerbe \\
\hline Tabakverarbeitung \\
\hline Textilgewerbe \\
\hline Bekleidungsgewerbe \\
\hline Holzgewerbe (ohne \\
Hen
\end{tabular}

Herstellung von Möbeln)
Helzgewerbe

Papiergewerbe 26

Verlagsgewerbe,

Vervielfältigung von

bespielten Ton-, Bild- und

Datenträgern

Chemische Industrie 28

\begin{tabular}{|l|l}
\hline Kokerei, \\
Mineralölverarbeitung,
\end{tabular}

Herstellung und Verarbeitung

von Spalt- und Brutstoffen

Herstellung von Gummi- und 30

Kunststoffwar

Ledergewerbe

\begin{tabular}{|l|l}
\hline Ledergewerbe & 31 \\
\cline { 1 - 2 } Verarbeitung von Steinen und &
\end{tabular}

Erden

Metallerzeugung- und

bearbeitung

Metallerzeugnissen

Maschinenbau

Herstellung von 36

Büroman,

Datenverarbeitungsgeräten

und -einrichtungen und

Herstellung von Geräten der

Elektrizitätserzeugung, -

verteilung $u$. ä. Und

Rundfunk-, Fernseh- und

Nachrichtentechnik

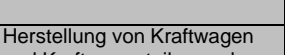

und Kraftwagenteilen und

Sonstiger Fahrzeugbau

Medizin-, Meß-, Steuer- und

Regelungstechnik, Optik
(2)

552906

12627

129038

78570

117678

147049

260021

487235

21757

358282

27881

256072

273094

599899

997302

654215

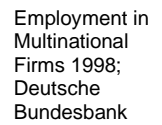

Employment of $\quad((2)-(3)) /(4)$ National Firms in Dataset in

1998

(3)

74000

8000

11000

8000

8000

40000

9000

120000

9000

$(4)$
131223

2902

7789

3409

8886

13973

27574

186575

17108

2.0

0.7

(5)

3.6

1.6

15.2

20.7

12.3

7.7

9.1

17087

147

Employment (3)/(6)

Multinationa

Firms in

Dataset in

1998

(6) (7)

$17001 \quad 4.4$

$3910 \quad 2.0$

$1704 \quad 6.5$

$1221 \quad 6.6$

0

$147 \quad 61.2$

$\begin{array}{lllll}68000 & 28079 & 10.3 & 15561 & 4.4\end{array}$

$2000 \quad 1762 \quad 14.7 \quad 0$

30000

19683

11.5

24356

48000

73509

3.1

4250

67000

37122

14.4

864

158000

134000

244164

59751

3.4

8.7

$75756 \quad 2.1$

$10528 \quad 12.7$ 
Next, we report representativeness of the firm data in table A2 by using aggregate data on German manufacturing firms for Germany for 1998 of Statistisches Bundesamt [50]. Unfortunately, the German industry code does not match exactly the US-SIC code of Amadeus. In general, there are 3 sectors more in the German classification. We report therefore the German industry classification by its German name and its match of the US-SIC code.

It is obvious that some sectors are overrepresented and others are under-represented. For example car industries is overrepresented. This may be so, because firm size of car manufacturers is rather large and those firms are not due to the size exclusion of Amadeus.

Next, we explore regional representativeness of our dataset. The data are shown in table A3. Wages do not vary much by region. However, the wage data from the Amadeus dataset are roughly one and a half time larger than those from Statistisches Bundesamt. This may be due to Statistisches Bundesamt reporting average wage costs for all sectors, while our Amadeus data only include manufacturing. It is well known that manufacturing wages are on average higher than wages in other sectors.

It is obvious that Eastern regions are under-represented. Note also that FDI of Saarland is larger in Amadeus than in the Bundesbank figures. This is well possible if some MNEs in Saarland do not report their employment figures to Bundesbank since this reporting is voluntary. In fact, the bulk of employment in FDI in Saarland stems from only one single French firm.

To cure for the problem of representativeness, we employ WLS estimation. We weight each observation according to the following procedure. Call $\mathrm{X}$ the ratio of employment in the database and in the official statistics of the year 1998 by region, $\mathrm{Y}$ the same variable by firm type (MNE/ not MNE), and $\mathrm{E}[$.$] the unconditional and \mathrm{E}[. .$.$] the conditional$ expected value. Then, we construct the weight $W$ according to Bayes-rule as follows by assuming independence of $\mathrm{Y}$ and $\mathrm{X}$ :

$$
W=E[Y \mid X] * E[X] .
$$

We chose not to correct for industry bias, since this produced too large a range of weights. In fact, we would have brought in additional noise by the estimation error of the weights. 
Our regression results, though, are not affected by the use of weights. Note, however, that we assumed that the regional/ industry structure of the population remains stable over time, since we have employed only aggregate data for the year 1998.

Table A3: Representativeness by Region

\begin{tabular}{|c|c|c|c|c|c|c|c|c|c|}
\hline Land & $\begin{array}{l}\text { FDI } \\
\text { employment } \\
\text { in } 1000 \text { in } \\
1998 ; \\
\text { Deutsche } \\
\text { Bundesbank }\end{array}$ & $\begin{array}{l}\text { MNE } \\
\text { Employ- } \\
\text { ment } \\
1998 ; \\
\text { Amadeus }\end{array}$ & $(2) /(1)$ & $\begin{array}{l}\text { Employees in } \\
\text { Manufac-turing } \\
\text { and Mining in } \\
\text { 1998; Stat. } \\
\text { Bundesamt }\end{array}$ & $\begin{array}{l}\text { Employ- } \\
\text { ment in } \\
\text { National } \\
\text { Firms in } \\
\text { 1998; } \\
\text { Amadeus }\end{array}$ & $((5)+(1)) /(4)$ & $\begin{array}{l}\text { Average } \\
\text { Wages in } \\
\text { DM per } \\
\text { employee in } \\
\text { 1998; Stat. } \\
\text { Bundesamt }\end{array}$ & $\begin{array}{l}\text { Average } \\
\text { Gross } \\
\text { Wage } \\
\text { Cost; } \\
\text { Amadeus }\end{array}$ & $(8) /(7)$ \\
\hline & (1) & (2) & (3) & (4) & (5) & (6) & (7) & (8) & (9) \\
\hline $\begin{array}{l}\text { Baden- } \\
\text { Württemberg }\end{array}$ & 277 & 49155 & 0.18 & 1244972 & 334715 & 0.31 & 68430 & 102.833 & 1.502 \\
\hline Bayern & 247 & 27216 & 0.11 & 1189416 & 248023 & 0.23 & 65940 & 103.162 & 1.564 \\
\hline Berlin & 49 & 7667 & 0.16 & 120949 & 31667 & 0.33 & 71278 & 88.9932 & 1.248 \\
\hline Brandenburg & 16 & 2809 & 0.18 & 94292 & 3256 & 0.06 & 50004 & 75.4185 & 1.508 \\
\hline Bremen & 28 & 5648 & 0.20 & 67440 & 8994 & 0.22 & 70772 & 96.7420 & 1.366 \\
\hline Hamburg & 95 & 19064 & 0.20 & 104057 & 34078 & 0.51 & 80259 & 113.774 & 1.417 \\
\hline Hessen & 311 & 104779 & 0.34 & 472420 & 105339 & 0.44 & 68875 & 125.275 & 1.818 \\
\hline $\begin{array}{l}\text { Mecklenburg- } \\
\text { Vorpommern }\end{array}$ & 9 & 1274 & 0.14 & 45981 & 2624 & 0.08 & 42795 & 68.8323 & 1.608 \\
\hline $\begin{array}{l}\text { Nieder- } \\
\text { sachsen }\end{array}$ & 90 & 24974 & 0.28 & 566917 & 51486 & 0.13 & 63672 & 104.507 & 1.641 \\
\hline $\begin{array}{l}\text { Nordrhein- } \\
\text { Westfalen }\end{array}$ & 397 & 108583 & 0.27 & 1528864 & 294206 & 0.26 & 65644 & 113.775 & 1.733 \\
\hline $\begin{array}{l}\text { Rheinland- } \\
\text { Pfalz }\end{array}$ & 44 & 6426 & 0.15 & 314687 & 99484 & 0.34 & 65252 & 96.9005 & 1.485 \\
\hline Saarland & 12 & 13580 & 1.13 & 107942 & 1196 & 0.14 & 62134 & 107.790 & 1.734 \\
\hline Sachsen & 16 & 0 & 0.00 & 214995 & 21429 & 0.10 & 44025 & 76.8086 & 1.744 \\
\hline $\begin{array}{l}\text { Sachsen- } \\
\text { Anhalt }\end{array}$ & 15 & 2001 & 0.13 & 104783 & 1430 & 0.03 & 44004 & 71.5093 & 1.625 \\
\hline $\begin{array}{l}\text { Schleswig- } \\
\text { Holstein }\end{array}$ & 48 & 2938 & 0.06 & 143580 & 8305 & 0.08 & 62343 & 90.7087 & 1.455 \\
\hline Thüringen & 13 & 2029 & 0.16 & 120002 & 3072 & 0.04 & 41255 & 79.9688 & 1.938 \\
\hline Deutschland & 1667 & 378143 & 0.23 & 6441297 & 1249304 & 0.25 & & 106.140 & \\
\hline
\end{tabular}

\section{B Data Description: Italy}

Firm data are from the database AIDA of Bureau van Dijk and are matched with ownership information from the MNE database of Politecnico Milano. Only manufacturing firms are 
included with information on a two-digit industry code (ATECO), the province name of the firm headquarter, and a dummy for foreign ownership participation. Whenever available, unconsolidated balance sheet data are used to avoid as much as possible multiplant firms, which may have production plants in regions other than the one where the headquarter is located. In general, all Italian manufacturing firms are included without size restriction. However, very small enterprises appear under-represented. Moreover the database is growing over time. While in the initial years only large firms are sampled, it remains unclear according to which sampling strategy the database is enlarged until it reaches full size (See table A4).

Table A4 : Number of Italian Firms by Year

$\begin{array}{cccccccc}\text { Year } & 1992 & 1993 & 1994 & 1995 & 1996 & 1997 & 1998 \\ \text { Number of firms } & 3712 & 4149 & 12257 & 20839 & 37500 & 42179 & 46588\end{array}$

When checking representativeness, we use ISTAT data on the Italian census of production in 1996 and 1991. Unfortunately, the industry codes of the census and of our firm database are largely incompatible. Hence, we can compare only the regional representativeness of our dataset. In 1996, there were a total of 5,514,650 employees in Italian manufacturing according to ISTAT. Our firm database employment coverage is $56 \%$ in this year. However, the correlation of manufacturing employment over 103 provinces from our firm database and from ISTAT is fairly high: 0.93. Therefore, we regard the Italian firm data as representative, at least from 1996 onwards.

For Italian firm data, we exclude all observations for which total assets per employee are smaller than 3 Million Lira or more than 2,364 Million Lira (which excludes the top and bottom 500 observations plus all observations with zero value), less than 50 Million Lira or more than 20000 Million sales per employee, less than 30 Million Lira or more than 1000 Million Lira average wage costs per employee, and less than 10 Million Lira or more than 20,000 Million Lira material costs per employee. As for German data, results are not very sensitive to these exclusion criteria (except summary statistics). 


\section{Tables and Figures}

Table 1: Descriptive Statistics Italy.

\begin{tabular}{lrrrr}
\hline & \multicolumn{2}{c}{ MNEs } & \multicolumn{2}{c}{$\begin{array}{c}\text { Indigenous } \\
\text { Firms }\end{array}$} \\
\cline { 2 - 6 } Variables: & North: & South: & North: & South: \\
\hline \hline Output per Employee & 535 & 543 & 527 & 559 \\
Fixed Assets per Employee & 148 & 79 & 208 & 157 \\
Material Imputs per Employee & 406 & 488 & 562 & 387 \\
Employees & 357 & 58 & 257 & 46 \\
Average Wage Cost/ Employee & 73 & 58 & 64 & 54 \\
\hline
\end{tabular}

Note: Data are average values of d'Agliano Dataset firms in 1998. Other years yield a similar picture. Units: Mill. LIT.

Table 2: Descriptive Statistics Germany.

\begin{tabular}{lrrrr}
\hline & \multicolumn{2}{c}{ MNEs } & \multicolumn{3}{c}{$\begin{array}{c}\text { Indigenous } \\
\text { Firms }\end{array}$} \\
\cline { 2 - 5 } Variables: & 845 & 687 & 517 & 707 \\
\hline \hline Output per Employee & West: & East*: & West: & East: \\
Fixed Assets per Employee & 1247 & 1100 & 901 & 865 \\
Material Imputs per Employee & 580 & 440 & 337 & 500 \\
Employees & 1662 & 2036 & 999 & 534 \\
Average Wage Cost/ Employee & 127 & 108 & 79 & 72 \\
\hline
\end{tabular}

Note: Data are average values within Amadeus Dataset for German firms in 1998. Other years yield a similar picture. Units: 1000 DM. * Also Eastern firms owned by Western companies are included. 


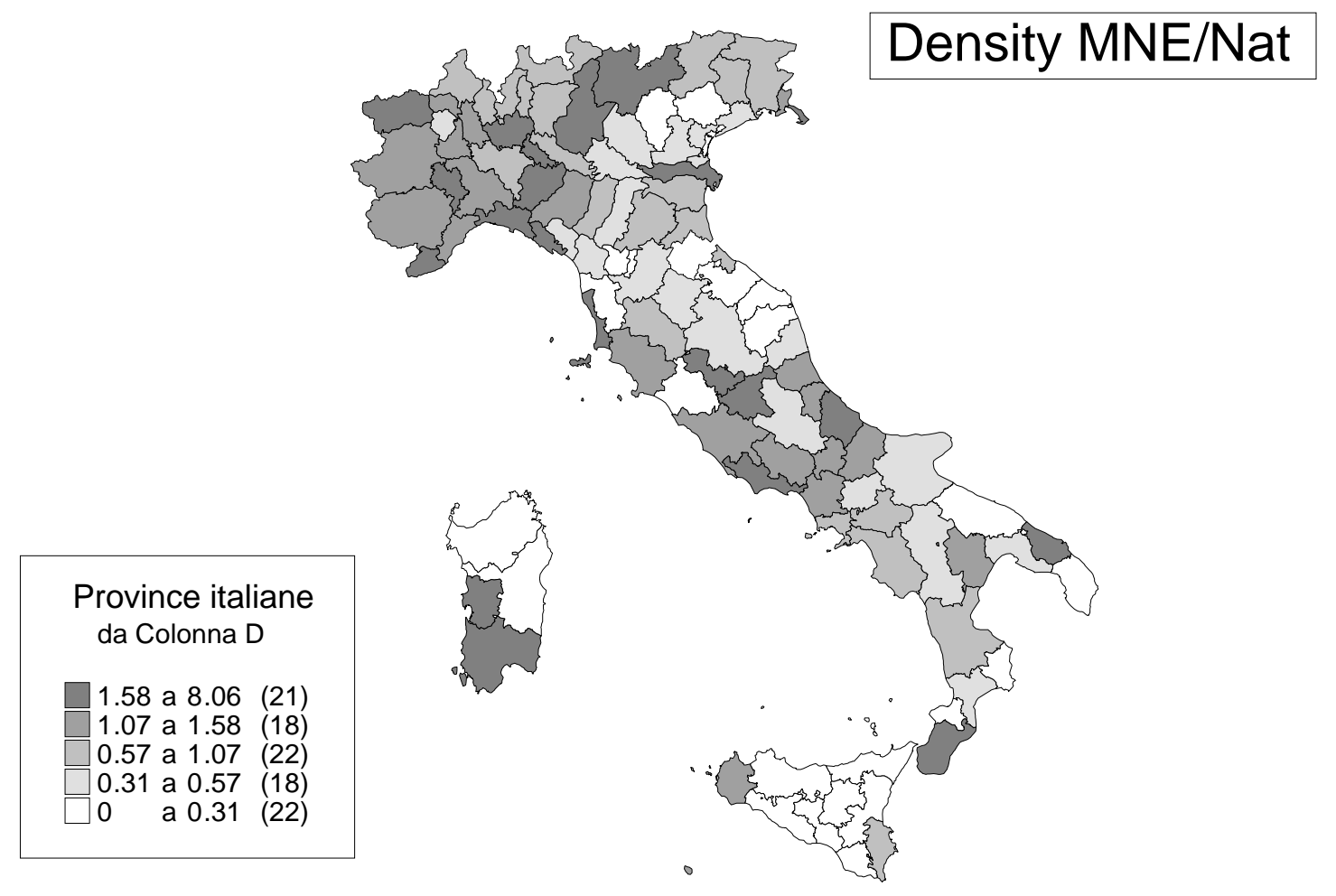

Figure 1: MNE Density in Italy 


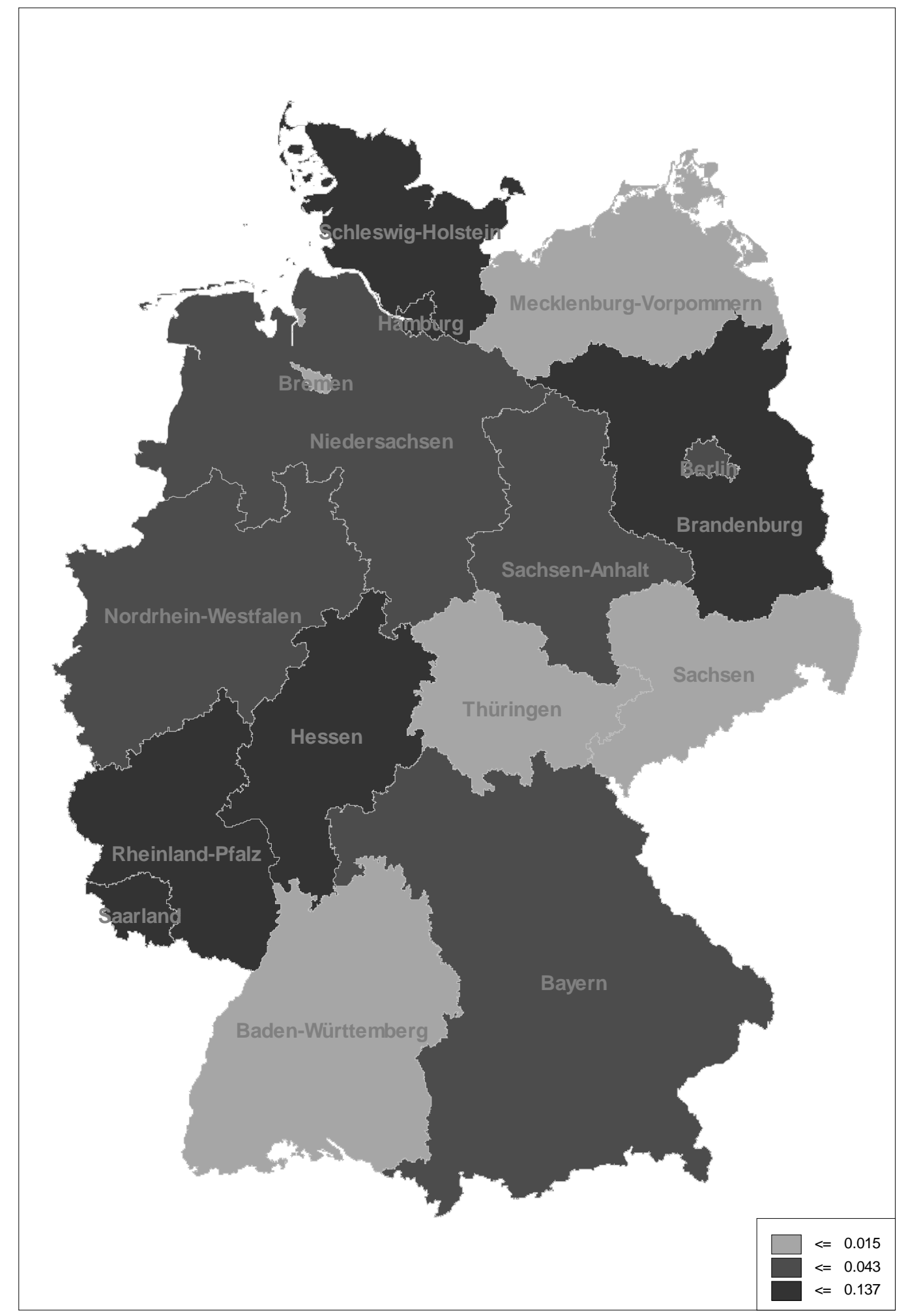

Figure 2: MNE Density in Germany 


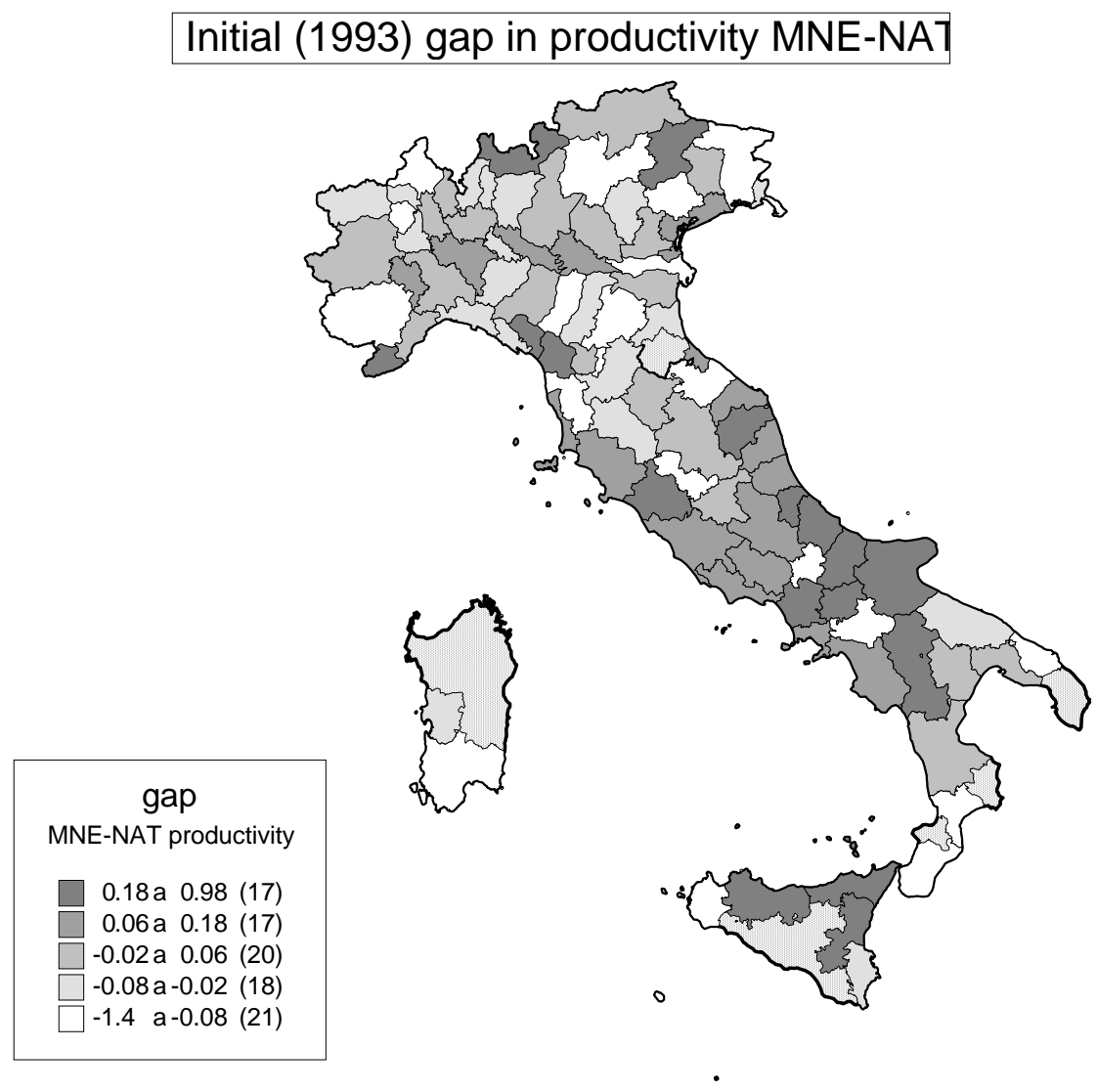

Figure 3: Gap in Productivity Foreign-National in 1993 


\section{Growth of National firm productivity 1993-98}

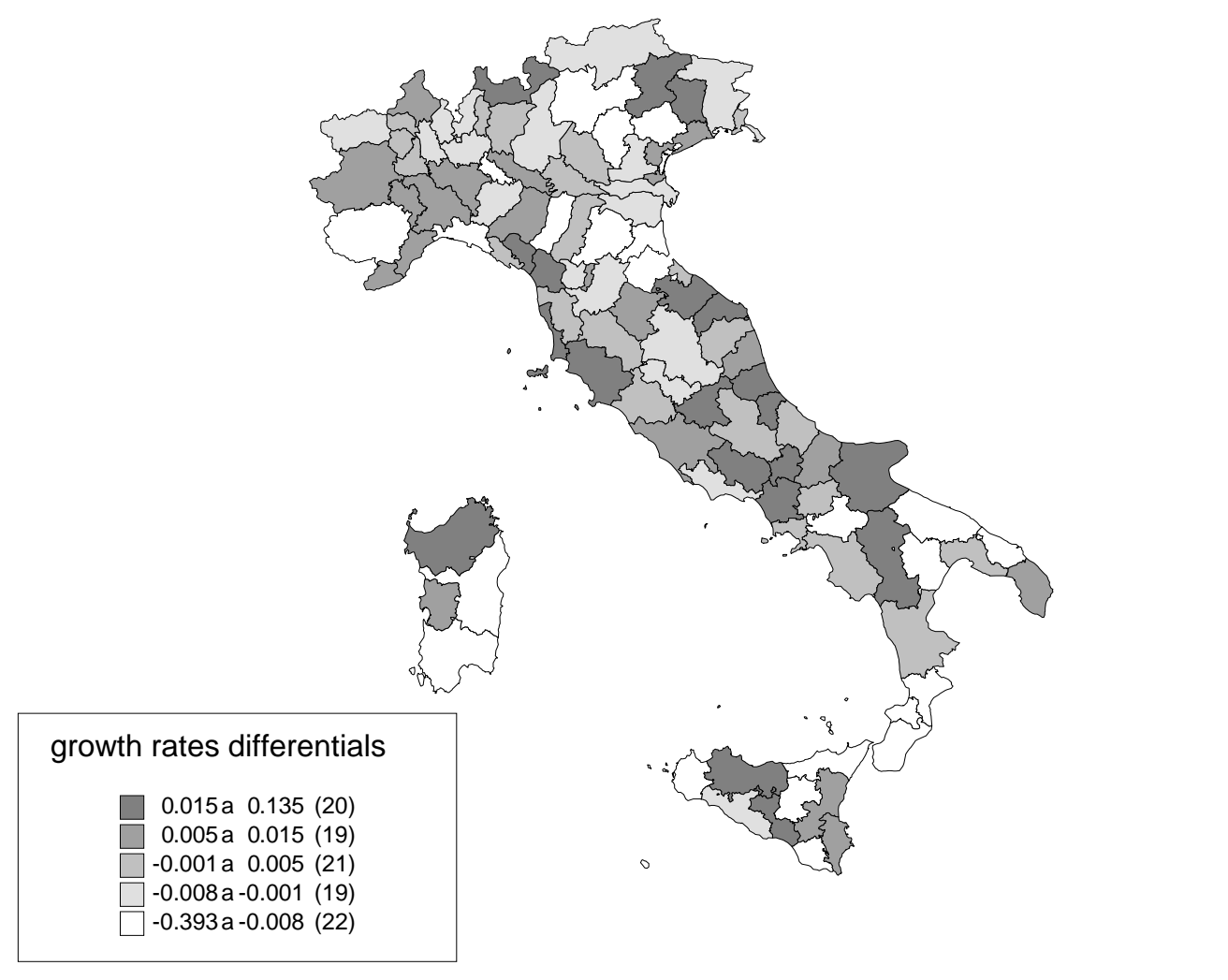

Figure 4: Growth in productivity National firms 1993-1998 


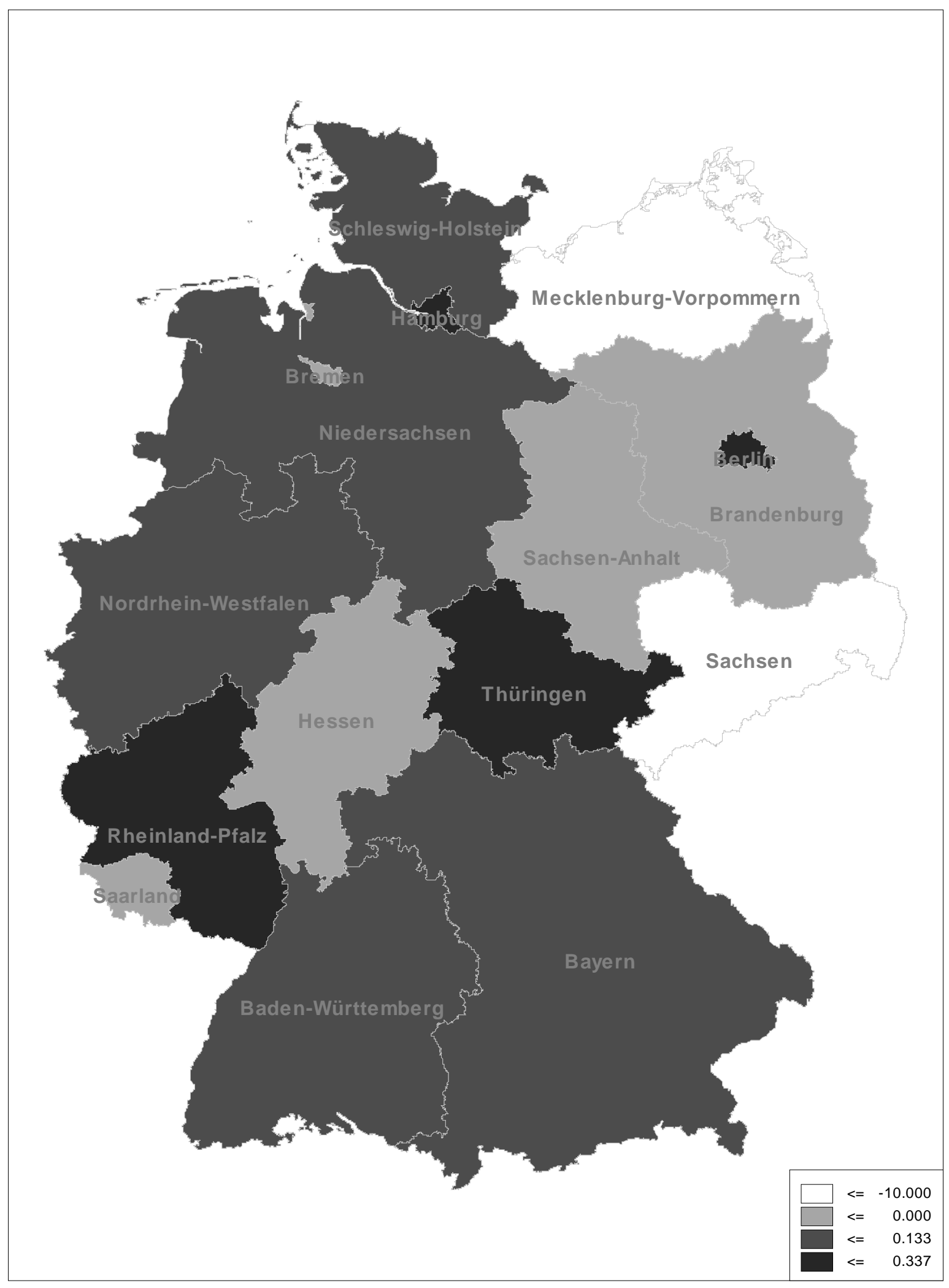

Figure 5: Gap in Productivity Foreign-Nationals 1993 


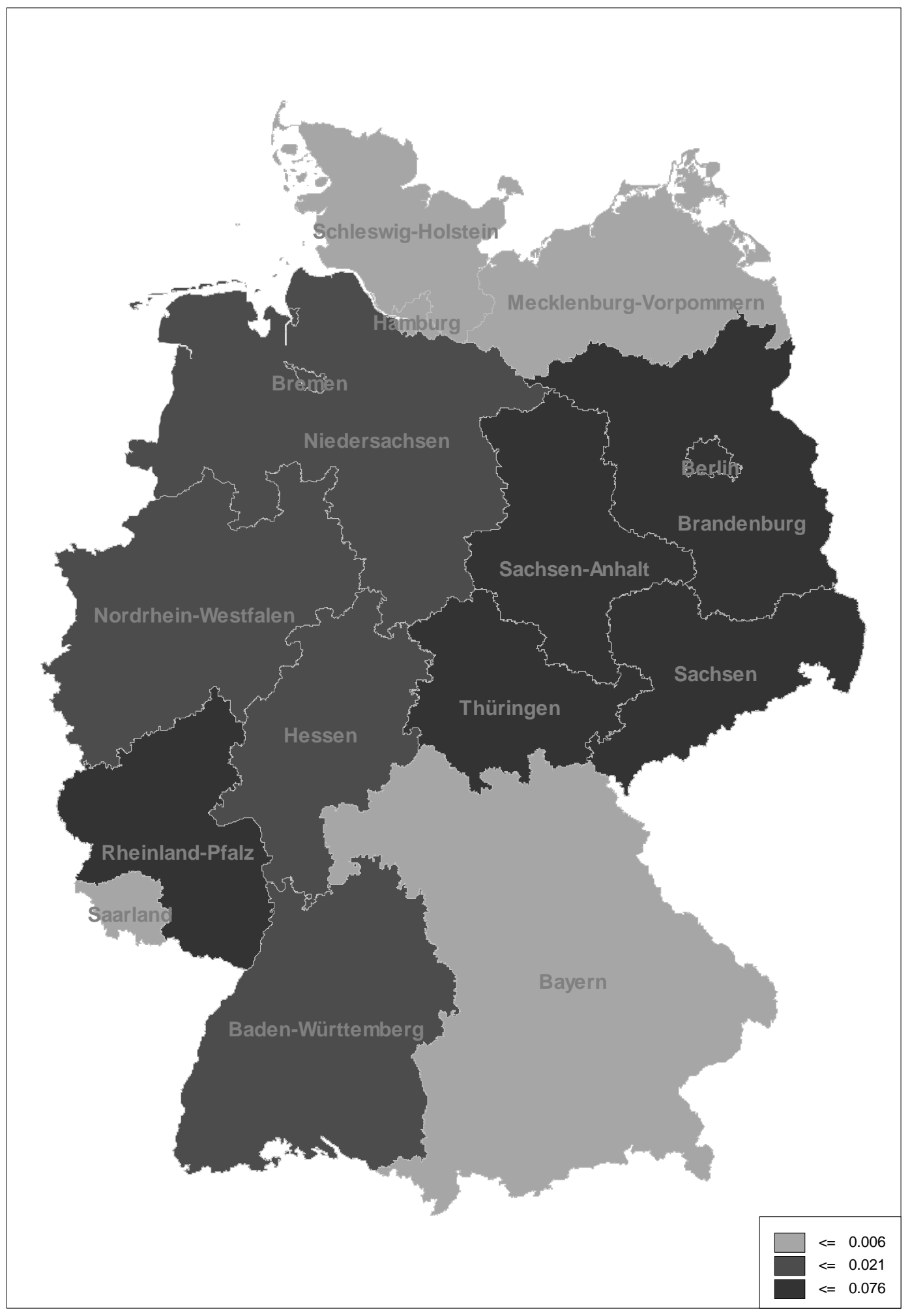

Figure 6: Growth in Productivity, National Firms 1993-98 
Table 3: First Stage Regressions.

\begin{tabular}{|c|c|c|c|c|}
\hline \multirow{3}{*}{$\begin{array}{l}\text { Dep. variable: } \\
\text { Country } \\
\text { Specification: }\end{array}$} & \multicolumn{4}{|c|}{ Firm Sales } \\
\hline & \multicolumn{2}{|c|}{ Italy } & \multicolumn{2}{|c|}{ Germany } \\
\hline & (I) & (II) & (III) & (IV) \\
\hline Employment & $\begin{array}{l}0.17^{* *} \\
(0.0004)\end{array}$ & $\begin{array}{l}0.17^{* *} \\
(0.0004)\end{array}$ & $\begin{array}{l}0.27^{* *} \\
(0.016)\end{array}$ & $\begin{array}{l}0.26^{* *} \\
(0.016)\end{array}$ \\
\hline Capital & $\begin{array}{l}0.03^{* *} \\
(0.004)\end{array}$ & $\begin{array}{l}0.03^{* *} \\
(0.004)\end{array}$ & $\begin{array}{l}0.10^{* *} \\
(0.013)\end{array}$ & $\begin{array}{l}0.10^{* *} \\
(0.12)\end{array}$ \\
\hline Material & $\begin{array}{l}0.78^{* *} \\
(0.004)\end{array}$ & $\begin{array}{l}0.78^{* *} \\
(0.004)\end{array}$ & $\begin{array}{l}0.58^{* *} \\
(0.013)\end{array}$ & $\begin{array}{l}0.58^{* *} \\
(0.012)\end{array}$ \\
\hline Foreign owned & $\begin{array}{l}0.02^{* *} \\
(0.004)\end{array}$ & & $\begin{array}{l}0.12^{* * *} \\
(0.015)\end{array}$ & \\
\hline $\begin{array}{l}\text { Indigenous Firm } \\
\text { in Poor Regions }\end{array}$ & & $\begin{array}{l}-0.019^{* *} \\
(-0.002)\end{array}$ & & $\begin{array}{l}-0.13^{* *} \\
(-0.04)\end{array}$ \\
\hline $\begin{array}{l}\text { MNE in Poor } \\
\text { Region }\end{array}$ & & $\begin{array}{l}-0.007^{* *} \\
(0.01)\end{array}$ & & $\begin{array}{l}-0.026^{* *} \\
(0.024)\end{array}$ \\
\hline $\begin{array}{l}\text { MNE in Rich } \\
\text { Region }\end{array}$ & & $\begin{array}{l}0.019^{* *} \\
(0.001)\end{array}$ & & $\begin{array}{l}0.118^{* *} \\
(0.0013)\end{array}$ \\
\hline Sector Dummies & Yes & Yes & Yes & Yes \\
\hline $\mathrm{R}^{2}(\%)$ & 98 & 98 & 92 & 92 \\
\hline Observations & 153992 & 153992 & 5132 & 5132 \\
\hline
\end{tabular}

Note: ${ }^{*},{ }^{* *}$, indicate the significance at the five percent and one percent level, respectively. Heteroscedasticity consistent standard errors are in parenthesis. Unreported year dummies and intercept are always included. Poor regions are the Eastern Laender in Germany and the Mezzogiorno in Italy. All variables are in logs except dummies. Estimates on Germany are WLS estimations with weight construction explained in the appendix. 
Table 4: Replicating spillover regressions with MNE employment shares.

\begin{tabular}{lcccc}
\hline \multirow{2}{*}{ Dep. variable: } & \multicolumn{4}{c}{ Firm Sales of Indigenous Firms } \\
\cline { 2 - 5 } Country & \multicolumn{3}{c}{ Italy } & \multicolumn{2}{c}{ Germany } \\
\cline { 2 - 5 } Specification: & $(\mathrm{I})$ & $(\mathrm{II})$ & $(\mathrm{III})$ & $(\mathrm{IV})$ \\
\hline \hline Employment & $0.17^{* *}$ & $0.14^{* *}$ & $0.19^{* *}$ & $0.22^{* *}$ \\
& $(0.0008)$ & $(0.003)$ & $(0.008)$ & $(0.009)$ \\
Capital & $0.03^{* *}$ & $0.03^{* *}$ & $0.26^{* *}$ & $0.29^{* *}$ \\
& $(0.0006)$ & $(0.0016)$ & $(0.015)$ & $(0.008)$ \\
Material & $0.78^{* *}$ & $0.78^{* *}$ & $0.52^{* *}$ & $0.45^{* *}$ \\
& $(0.0009)$ & $(0.004)$ & $(0.014)$ & $(0.007)$ \\
MNE employment & $0.018^{* *}$ & 0.003 & $0.78^{* *}$ & -0.36 \\
share & $(0.003)$ & $(0.006)$ & $(0.16)$ & $(0.71)$ \\
Time Dummies & Yes & Yes & Yes & Yes \\
Sector Dummies & Yes & No & No & No \\
Region Dummies & Yes & No & No & No \\
Firm Fixed Effects & No & Yes & No & Yes \\
\hline \hline R ${ }^{2}$ (\%) & 98 & 99 & 93 & 93 \\
Observations & 147809 & 147809 & 3823 & 3823 \\
\hline
\end{tabular}

Note: ${ }^{*},{ }^{* *}$, indicate the significance at the five percent and one percent level, respectively. Heteroscedasticity consistent standard errors are in parenthesis. Unreported year dummies and intercept are always included. All variables are in logs except dummies and MNE employment share. No correction for weights are made in regressions on Germany. 
Table 5: Second Stage Regressions for Italy.

\begin{tabular}{lcccc}
\hline Dep. variable: & \multicolumn{4}{c}{ Average Productivity Growth of Indigenous Firms } \\
\cline { 2 - 5 } Estimation: & \multicolumn{3}{c}{ OLS } & \multicolumn{2}{c}{ IV } \\
\cline { 2 - 5 } Specification: & $(\mathrm{I})$ & $(\mathrm{II})$ & $(\mathrm{III})$ & $(\mathrm{IV})$ \\
\hline \hline Initial Productivity & $-0.08^{* * *}$ & $-0.08^{* * *}$ & $-0.06^{* * *}$ & $-0.06^{* * *}$ \\
indigenous firms & $(0.01)$ & $(0.01)$ & $(0.02)$ & $(0.02)$ \\
Gap & $0.014^{* * *}$ & $0.013^{* * *}$ & $0.020^{*}$ & $0.019^{*}$ \\
& $(0.005)$ & $(0.005)$ & $(0.012)$ & $(0.012)$ \\
MNE density & & -0.004 & & -0.004 \\
& & $(0.006)$ & & $(0.004)$ \\
\hline \hline $\mathrm{R}^{2}(\%)$ & 50 & 50 & 45 & 45 \\
Observations & 483 & 483 & 447 & 447 \\
\hline
\end{tabular}

Note: ${ }^{*},{ }^{* *},{ }^{* *}$ indicate the significance at the ten, five, and one percent level, respectively.

Heteroscedasticity consistent standard errors are in parenthesis. Unreported intercept is always included. Instruments: initial productivity, gap and productivity growth obtained from first stage regressions with average wage cost per employee as dependent variable, the $\log$ of referendum participation in 1974 and the log of murder cases in 1985. Observations are indexed by sector and province. 
Table 6: Second Stage Regression Robustness Check for Italy.

\begin{tabular}{|c|c|c|c|c|}
\hline \multirow{3}{*}{$\begin{array}{l}\text { Dep. variable: } \\
\text { Estimation: } \\
\text { Specification: }\end{array}$} & \multicolumn{4}{|c|}{ Average Productivity Growth of Indigenous Firms } \\
\hline & \multicolumn{2}{|c|}{ OLS } & \multicolumn{2}{|c|}{ IV } \\
\hline & (I) & (II) & (III) & $(\mathrm{IV})$ \\
\hline $\begin{array}{l}\text { Initial Productivity } \\
\text { indigenous firms }\end{array}$ & $\begin{array}{l}-0.07 * * * \\
(0.01)\end{array}$ & $\begin{array}{l}-0.05^{* * *} \\
(0.01)\end{array}$ & $\begin{array}{l}-0.15^{* *} \\
(0.06)\end{array}$ & $\begin{array}{l}-0.92 \\
(19.30)\end{array}$ \\
\hline Gap & $\begin{array}{l}0.015^{* * *} \\
(0.008)\end{array}$ & $\begin{array}{l}0.014^{* * *} \\
(0.004)\end{array}$ & & \\
\hline MNE density & $\begin{array}{l}-0.007 \\
(0.006)\end{array}$ & $\begin{array}{l}-0.002 \\
(0.005)\end{array}$ & $\begin{array}{l}0.014 \\
(0.040)\end{array}$ & $\begin{array}{l}-0.47 \\
(11.03)\end{array}$ \\
\hline log referendum 1974 & $\begin{array}{l}-0.08^{* *} \\
(0.04)\end{array}$ & & & \\
\hline log murder 1985 & $\begin{array}{l}-0.02 \\
(0.02)\end{array}$ & & & \\
\hline log illiterate 1991 & $\begin{array}{l}-0.0005 \\
(0.001)\end{array}$ & & & \\
\hline no. plant growth & & & 0.63 & \\
\hline $1991-1996$ & & & $(1.71)$ & \\
\hline $\begin{array}{l}\text { employment } \\
\text { growth 1991-1996 }\end{array}$ & & & & $\begin{array}{r}-0.47 \\
(11.03)\end{array}$ \\
\hline Province Dummies & No & Yes & No & No \\
\hline $\mathrm{R}^{2}(\%)$ & 48 & 73 & & \\
\hline Obs & 452 & 483 & 420 & 420 \\
\hline
\end{tabular}

Note: ${ }^{*},{ }^{* *},{ }^{* *}$ indicate the significance at the ten, five, and one percent level, respectively. Heteroscedasticity consistent standard errors are in parenthesis. Unreported intercept is always included. Instrument: gap-variable. Observations are indexed by sector and province. 
Table 7: Second Stage Regressions for Germany.

\begin{tabular}{lcccc}
\hline \multirow{2}{*}{ Dep. variable: } & \multicolumn{4}{c}{ Average Productivity Growth of Indigenous Firms } \\
\cline { 2 - 5 } Estimation: & \multicolumn{3}{c}{ OLS } & \multicolumn{2}{c}{ IV } \\
\cline { 2 - 5 } Specification: & $-0.43^{* * *}$ & $-0.45^{* * *}$ & $-0.48^{*}$ & -0.59 \\
\cline { 2 - 5 } & $(0.11)$ & $(0.13)$ & $(0.25)$ & $(0.48)$ \\
Initial Productivity & $0.23^{* * *}$ & $0.22^{* * *}$ & $0.63^{*}$ & $0.59^{*}$ \\
lagged gap & $(0.07)$ & $(0.08)$ & $(0.33)$ & $(0.30)$ \\
& & 0.006 & & 0.015 \\
lagged log MNE density & & $(0.02)$ & & $(0.042)$ \\
Time Dummies & Yes & Yes & Yes & Yes \\
\hline \hline R ${ }^{2}(\%)$ & 41 & 41 & 21 & 22 \\
Obs & 86 & 86 & 82 & 82 \\
\hline
\end{tabular}

Note: ${ }^{*},{ }^{* *},{ }^{* * *}$ indicate the significance at the ten, five, and one percent level, respectively.

Heteroscedasticity consistent standard errors are in parenthesis. Unreported intercept is always included. Initial productivity and MNE density are in logs. Instruments: one periodlagged Initial GDP per capita, productivity growth of domestic firms and MNEs obtained from first stage regressions with average wage cost per employee as dependent variable. Observations are indexed by region and year. 
Table 8: Second Stage Regression Robustness Check for Germany.

\begin{tabular}{|c|c|c|c|c|}
\hline Dep. variable: & Average $\operatorname{Pr}$ & tivity Gror & th of Indig & ous Firms \\
\hline Estimation: & OLS & IV & OLS & $\operatorname{AR}(1)$ \\
\hline Specification: & (I) & (II) & (III) & (IV) \\
\hline $\begin{array}{l}\text { Initial Productivity } \\
\text { indigenous firms }\end{array}$ & $\begin{array}{l}-0.57^{* * *} \\
(0.17)\end{array}$ & $\begin{array}{l}-0.57^{* * *} \\
(0.18)\end{array}$ & $\begin{array}{l}-0.47^{* * *} \\
(0.13)\end{array}$ & $\begin{array}{c}0.06 \\
(0.29)\end{array}$ \\
\hline Gap & $\begin{array}{l}0.25^{* *} \\
(0.10)\end{array}$ & & $\begin{array}{l}0.22^{* * *} \\
(0.08)\end{array}$ & $\begin{array}{l}0.89^{* * *} \\
(0.32)\end{array}$ \\
\hline MNE density & $\begin{array}{l}-0.002 \\
(0.02)\end{array}$ & $\begin{array}{l}-0.03 \\
(0.05)\end{array}$ & & $\begin{array}{l}-0.24^{*} \\
(0.13)\end{array}$ \\
\hline $\begin{array}{l}\text { Lagged log share of university } \\
\text { graduates in population }\end{array}$ & $\begin{array}{l}0.09^{*} \\
(0.05)\end{array}$ & & & \\
\hline lagged log of investment & -0.08 & & & \\
\hline per inhabitant & $(0.06)$ & & & \\
\hline employment growth & & $\begin{array}{l}-0.19 \\
(0.13)\end{array}$ & & \\
\hline $\begin{array}{l}\text { lagged ratio of FDI stock } \\
\text { and total capital stock }\end{array}$ & & & $\begin{array}{l}0.015 \\
(0.018)\end{array}$ & \\
\hline Time Dummies & Yes & Yes & Yes & No \\
\hline $\mathrm{R}^{2}(\%)$ & 54 & & 42 & \\
\hline Obs & 70 & 86 & 80 & 69 \\
\hline
\end{tabular}


Table 9: Absorptive Capacity.

\begin{tabular}{|c|c|c|c|c|}
\hline \multirow{3}{*}{$\begin{array}{l}\text { Dep. variable: } \\
\text { Country: } \\
\text { Specification: }\end{array}$} & \multicolumn{4}{|c|}{ Average TFP growth of indigenous firms } \\
\hline & \multicolumn{2}{|c|}{ Germany } & \multicolumn{2}{|c|}{ Italy } \\
\hline & Above threshold & Below Threshold & Above threshold & Below Threshold \\
\hline gap & $\begin{array}{l}0.16^{* *} \\
(0.08)\end{array}$ & $\begin{array}{l}0.24^{* *} \\
(0.11)\end{array}$ & $\begin{array}{l}0.04^{* * *} \\
(0.01)\end{array}$ & $\begin{array}{l}0.01^{* * *} \\
(0.005)\end{array}$ \\
\hline MNE density & $\begin{array}{c}0.02 \\
(0.02)\end{array}$ & & $\begin{array}{r}-0.0004 \\
(0.0003)\end{array}$ & \\
\hline initial TFP & $\begin{array}{l}-0.60^{* * *} \\
(0.19)\end{array}$ & & $\begin{array}{l}-0.07^{* * *} \\
(0.01)\end{array}$ & \\
\hline constant & $\begin{array}{l}1.7^{* * *} \\
(0.53)\end{array}$ & $\begin{array}{l}1.65^{* * *} \\
(0.52)\end{array}$ & $\begin{array}{l}0.10^{* * *} \\
(0.01)\end{array}$ & $\begin{array}{l}0.09^{* * *} \\
(0.02)\end{array}$ \\
\hline $\begin{array}{l}\text { Threshold Value of } \\
\text { HUMCAP }\end{array}$ & -2.25 & & 0.023 & \\
\hline Sup- Wald Test & $\begin{array}{c}5.46 \\
(0.37)\end{array}$ & & $\begin{array}{l}9.54 \\
(0.21)\end{array}$ & \\
\hline Breusch-Pagan Test & $0.00^{* * *}$ & & $0.00 * * *$ & \\
\hline Joint $\mathrm{R}^{2}(\%)$ & 54.1 & & 49.5 & \\
\hline Obs & 52 & 21 & 241 & 212 \\
\hline $\begin{array}{l}\text { Note: }{ }^{* *},{ }^{* *},{ }^{*} \\
\text { level, respectively } \\
\text { observations are } \\
\text { are included for } \\
\text { the share of popt } \\
1981 \text { for Italy; Oı } \\
\text { halfs; Sup-Wald } \\
\text { in parenthesis is } \\
\text { heteroscedasticity }\end{array}$ & $\begin{array}{l}\text { ndicate the signifi } \\
\text { Heteroscedasticit } \\
\text { region and 2-digi } \\
\text { aly. They are sig } \\
\text { ation with univers } \\
\text { y the gap variable } \\
\text { st for significance } \\
\text { otained from a bo }\end{array}$ & $\begin{array}{l}\text { nce at the one pe } \\
\text { consistent standar } \\
\text { industry classificat } \\
\text { ificant according t } \\
y \text { degree lagged on } \\
\text { nd the constant ar } \\
\text { f threshold: See H } \\
\text { tstrap with } 1000 \mathrm{r}\end{array}$ & $\begin{array}{l}\text { ent, five percent a } \\
\text { errors are in pare } \\
\text { n. Unreported pro } \\
\text { an F-test: Thresh } \\
\text { year for Germany } \\
\text { allowed to vary acr } \\
\text { ason (2000); Margi } \\
\text { lications; Breusch- }\end{array}$ & $\begin{array}{l}\text { ten percent } \\
\text { hesis. Italian } \\
\text { nce dummies } \\
\text { ld variable is } \\
\text { d in the year } \\
\text { ss the sample } \\
\text { al probability } \\
\text { agan test for }\end{array}$ \\
\hline
\end{tabular}

